\title{
Streamflow Record Extension for Selected Streams in the Susitna River Basin, Alaska
}

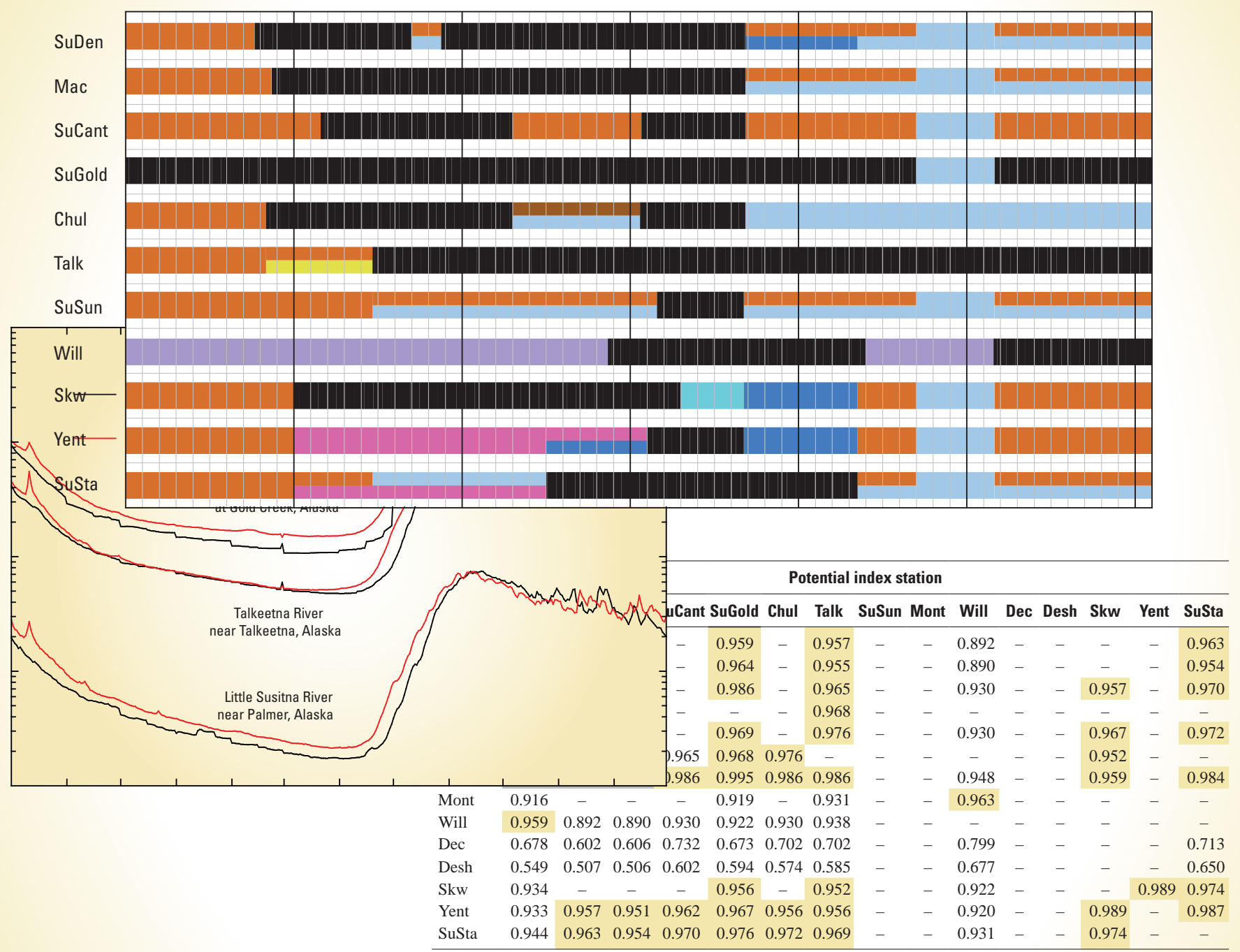

Scientific Investigations Report 2012-5210

U.S. Department of the Interior

U.S. Geological Survey 



\section{Streamflow Record Extension for Selected Streams in the Susitna River Basin, Alaska}

By Janet H. Curran

Prepared in cooperation with the Alaska Energy Authority

Scientific Investigations Report 2012-5210 


\section{U.S. Department of the Interior \\ KEN SALAZAR, Secretary \\ U.S. Geological Survey \\ Marcia K. McNutt, Director}

U.S. Geological Survey, Reston, Virginia: 2012

For more information on the USGS - the Federal source for science about the Earth, its natural and living resources, natural hazards, and the environment, visit http://www.usgs.gov or call 1-888-ASK-USGS.

For an overview of USGS information products, including maps, imagery, and publications, visit http://www.usgs.gov/pubprod

To order this and other USGS information products, visit http://store.usgs.gov

Any use of trade, product, or firm names is for descriptive purposes only and does not imply endorsement by the U.S. Government.

Although this report is in the public domain, permission must be secured from the individual copyright owners to reproduce any copyrighted materials contained within this report.

Suggested citation:

Curran, J.H., 2012, Streamflow record extension for selected streams in the Susitna River Basin, Alaska: U.S.

Geological Survey Scientific Investigations Report 2012-5210, 36 p. 


\section{Contents}

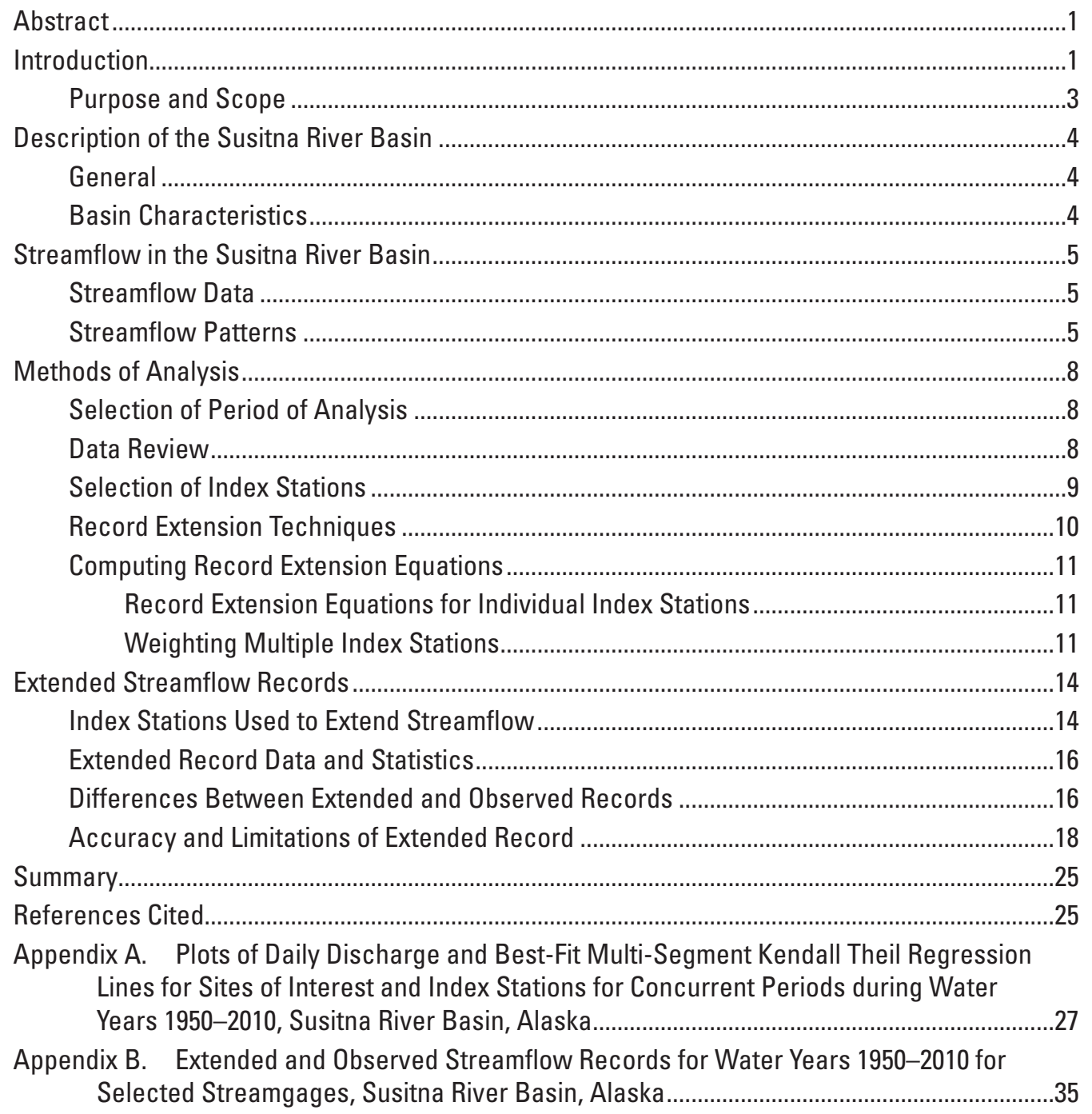




\section{Figures}

Figure 1. Map showing location and streamgages used in the study of Susitna River Basin, Alaska

Figure 2. Graph showing periods of observed record for selected streamgages in and near the Susitna River Basin, Alaska, and phase of the Pacific Decadal Oscillation (PD0) for water years 1950-2010

Figure 3. Graphs showing mean daily discharge for selected streamgages in and near the Susitna River Basin, Alaska, categorized by relative contribution of glacier melt, snowmelt, and rainfall

Figure 4. Graph showing index values and phase shifts in the Pacific Decadal Oscillation, 1920-2011

Figure 5. Graph showing variability in mean daily discharge during the most recent cool phase and warm phase of the Pacific Decadal Oscillation for primary index stations in and near the Susitna River Basin, Alaska

Figure 6. Graphs showing examples of predicted and observed discharge values for selected streamgages in the Susitna River Basin, Alaska

Figure 7. Graph showing index stations used to extend streamflow records in the Susitna River Basin, Alaska

Figure 8. Graphs showing mean daily discharge for composite (observed and extended) records for water year 1950-2010 and observed records for the available period of record for selected streamgages, Susitna River Basin, Alaska....

\section{Tables}

Table 1. Basin characteristics for selected streams in and near the Susitna River Basin, Alaska

Table 2. Correlation coefficients (Pearson's r) between logarithms of daily discharge values at sites of interest and potential index stations for streams in the Susitna

River Basin, Alaska

Table 3. Values for variables, discharge input ranges, and measures of error for equations for estimating daily discharge from index station data at selected streamgages,

Susitna River Basin, Alaska

Table 4. Periods of observed and extended streamflow records and index stations used for record extension for selected streamgages, Susitna River Basin, Alaska

Table 5. Mean monthly discharge for composite (observed and extended) records for selected streamgages in the Susitna River Basin, Alaska, water years 1950-2010

Table 6. Difference in mean monthly discharge between composite (observed and extended) records and observed records for selected streamgages in the Susitna River Basin, Alaska, water years 1950-2010.

Table 7. Annual mean discharge for composite (observed and extended) records for selected streamgages in the Susitna River Basin, Alaska, water years 1950-2010

Table 9. Nash Sutcliffe efficiency (NSE) coefficients comparing observed and predicted discharge values at selected streamgages in the Susitna River Basin, Alaska

Table 8. Mean annual discharge for composite (observed and extended) records and difference from observed records for selected streamgages in the Susitna River Basin, Alaska, water years 1950-2010 


\title{
Conversion Factors, Datums, and Abbreviations and Acronyms
}

\author{
Conversion Factors
}

\begin{tabular}{|c|c|c|}
\hline Multiply & By & To obtain \\
\hline \multicolumn{3}{|c|}{ Length } \\
\hline $\begin{array}{l}\text { inch (in.) } \\
\text { inch (in.) } \\
\text { foot (ft) } \\
\text { mile (mi) }\end{array}$ & $\begin{array}{l}2.54 \\
25.4 \\
0.3048 \\
1.609\end{array}$ & $\begin{array}{l}\text { centimeter }(\mathrm{cm}) \\
\text { millimeter }(\mathrm{mm}) \\
\text { meter }(\mathrm{m}) \\
\text { kilometer }(\mathrm{km})\end{array}$ \\
\hline \multicolumn{3}{|c|}{ Area } \\
\hline $\begin{array}{l}\text { square mile }\left(\mathrm{mi}^{2}\right) \\
\text { square mile }\left(\mathrm{mi}^{2}\right)\end{array}$ & $\begin{array}{l}259.0 \\
2.590\end{array}$ & $\begin{array}{l}\text { hectare (ha) } \\
\text { square kilometer }\left(\mathrm{km}^{2}\right)\end{array}$ \\
\hline \multicolumn{3}{|c|}{ Flow Rate } \\
\hline cubic foot per second $\left(\mathrm{ft}^{3} / \mathrm{s}\right)$ & 0.02832 & cubic meter per second $\left(\mathrm{m}^{3} / \mathrm{s}\right)$ \\
\hline
\end{tabular}

Temperature in degrees Fahrenheit $\left({ }^{\circ} \mathrm{F}\right)$ may be converted to degrees Celsius $\left({ }^{\circ} \mathrm{C}\right)$ as follows:

${ }^{\circ} \mathrm{C}=\left({ }^{\circ} \mathrm{F}-32\right) / 1.8$.

Datums

Vertical coordinate information is referenced to the North American Vertical Datum of 1929 (NAVD 29).

Horizontal coordinate information is referenced to the North American Vertical Datum of 1983 (NAD 83).

Elevation, as used in this report, refers to distance above the vertical datum.

Abbreviations and Acronyms

\begin{tabular}{ll}
\hline $\begin{array}{c}\text { Abbreviation or } \\
\text { Acronym }\end{array}$ & \multicolumn{1}{c}{ Definition } \\
\hline AEA & Alaska Energy Authority \\
KTRL & Kendall-Theil Robust Line \\
LOWESS & locally-weighted scatterplot smoothing \\
MOVE & Maintenance of Variance-Extension \\
MSE & mean square error \\
NSE & Nash-Suttcliffe efficiency \\
NWIS & National Water Information System \\
PDO & Pacific Decadal Oscillation \\
RMSE & root mean square error \\
USGS & U.S. Geological Survey \\
WY & water year \\
\hline
\end{tabular}


This page intentionally left blank 


\title{
Streamflow Record Extension for Selected Streams in the Susitna River Basin, Alaska
}

\author{
By Janet H. Curran
}

\begin{abstract}
Daily streamflow records for water years 1950-2010 in the Susitna River B asin range in length from 4 to 57 years, and many are distributed within that period in a way that might not adequately represent long-term streamflow conditions. Streamflow in the basin is affected by the Pacific Decadal Oscillation (PDO), a multi-decadal climate pattern that shifted from a cool phase to a warm phase in 1976. Records for many streamgages in the basin fell mostly within one phase of the PDO, such that monthly and annual statistics from observed records might not reflect streamflow conditions over a longer period. Correlations between daily discharge values sufficed for extending streamflow records at 11 of the 14 streamgages in the basin on the basis of relatively long-term records for one or more of the streamgages within the basin, or one outside the basin, that were defined as index stations. Streamflow at the index stations was hydrologically responsive to glacier melt and snowmelt, and correlated well with flow from similar high-elevation, glaciated basins, but flow in low-elevation basins without glaciers could not be correlated to flow at any of the index stations. K endall-Theil Robust Line multi-segment regression equations developed for one or more index stations were used to extend daily discharge values to the full 61-year period for all 11 streamgages. M onthly and annual statistics prepared for the extended records show shifts in timing of breakup and freeze-up and magnitude of snowmelt peaks largely predicted by the PDO phase.
\end{abstract}

\section{Introduction}

In 2010, the A laska Energy A uthority (AEA) declared the intent to pursue development of a large hydroelectric project on the Susitna River, A laska (ig. 1) to meet projected energy needs for southcentral and interior A laska. The Susitna-Watana Project entered the federal licensing process in 2011. The A EA proposes construction of a single dam on the river near Watana Creek, about 90 river miles northeast of Talkeetna, at the same location as the upstream-most of two sites proposed for a hydroelectric project pursued from the early 1980s until 1986 (A laska Energy A uthority, 2011). The proposed Susitna-Watana dam would alter the natural flow of the Susitna River downstream of the dam site and replace it with a load-following operating regime that would increase winter flows to meet peak energy needs and decrease summer flows to refill the reservoir. This regulation would dampen the natural difference between low flows in the winter and high flows in the summer downstream of the dam site.

Designing and evaluating potential impacts of the proposed Susitna-Watana project required streamflow information beyond the observed streamflow values available for the U.S. Geological Survey (USGS) streamgages in the Susitna River B asin. A $n$ unbroken record of daily discharge values was needed for engineering purposes such as modeling the power generation capacity of the proposed dam and for environmental assessments such as the ecosystem response to changes in the timing and range of variability of altered flows. Natural variations in streamflow at an annual scale, coupled with known multi-decadal variations driven by the Pacific Decadal Oscillation (PDO) (Neal and others, 2002; Hodgkins, 2009), increase the need for the longest period of record possible to account for the inability of short records to represent long-term conditions. For the 61-year period from water year (WY) 1950 to WY 2010, the 14 USGS streamgages in the Susitna River Basin that capture daily discharge values have record lengths ranging from 4 to 57 years (fig. 2). Several of these records fall entirely within one phase of the PDO, resulting in a likely misrepresentation of long-term streamflow patterns. 

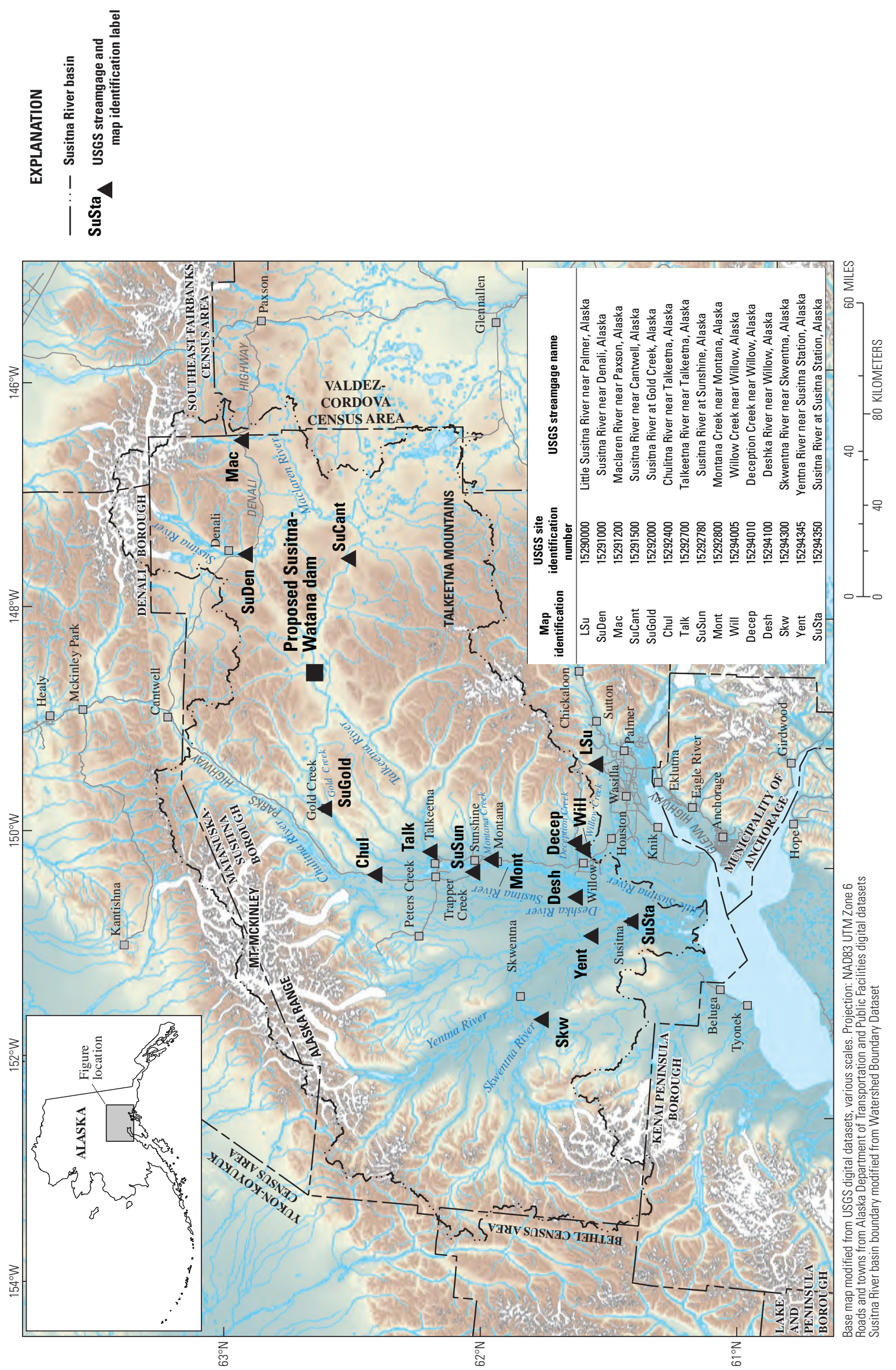

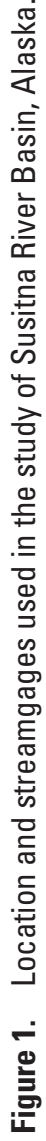


Streamflow analysis methods have been developed to enable record extension, or estimation of values for a short-record station on the basis of a longer record at an index station, when daily discharge values are closely correlated. Record extension creates a continuous string of daily values at the short-record streamgage for the period of record of the longer-record streamgage. Opportunities for extending streamflow records in Alaska are typically limited by the lack of closely-spaced streamgages with concurrent record, but the relatively large population and road density in the Susitna River Basin, coupled with the early recognition of the potential for hydropower generation, resulted in the collection of more streamflow data in the basin than is typical for the state. Streamgages have been operated simultaneously for certain periods at multiple locations on the Susitna River, and all major tributaries to the river have been gaged at some time. The Susitna River at Gold Creek streamgage has a nearly-unbroken, long-term record that overlaps records from all other streamgages. A $n$ additional streamgage, Little
Susitna River near Palmer, neighbors the Susitna River Basin and has an unbroken record for the study period. The large size of many of the gaged streams and the common presence of glaciers in their basins increases the chance of streamflow correlation. The combination of data availability and similarity of basin characteristics make record extension feasible for much of the Susitna River Basin streamgaging network.

\section{Purpose and Scope}

This report presents the results of a USGS study conducted in cooperation with the AEA to enhance streamflow records in the Susitna River Basin. The study explored the suitability of record extension for the 14 USGS streamgages in the basin that had records within the period WY 1950-2010, extended discharge records for suitable streamgages, and estimated long-term monthly and annual streamflow statistics for the extended record period of WY 1950-2010.

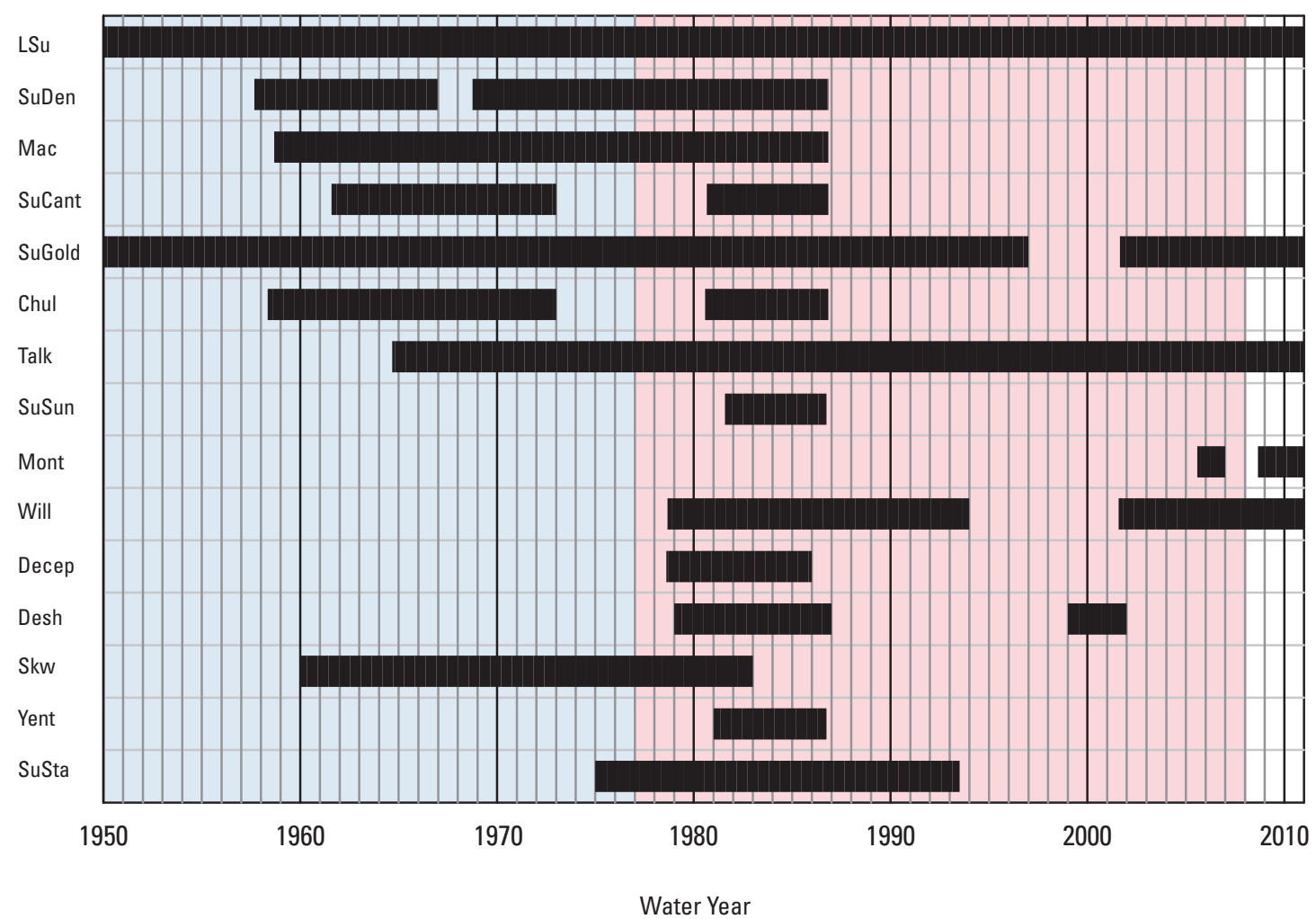

EXPLANATION

Observed data

Cool phase of the Pacific Decadal Oscillation

Warm phase of the Pacific Decadal Oscillation

Figure 2. Periods of observed record for selected streamgages in and near the Susitna River Basin, Alaska, and phase of the Pacific Decadal Oscillation (PDO) for water years 1950-2010. Locations, full station names, numbers, and map identifiers are shown in figure 1. 


\section{Description of the Susitna River Basin}

\section{General}

The Susitna River drains a 20,010 $\mathrm{mi}^{2}$ basin containing parts of the A laska R ange and the Talkeetna M ountains, a high plateau including the $23 \mathrm{mi}^{2}$ Lake L ouise, and an extensive lowland in the Matanuska-Susitna Borough of southcentral A laska. Elevations in the basin range from $20,320 \mathrm{ft}$ at the summit of M t. M cK inley to sea level at the river mouth (fig. 1). Glaciers, which are common on higher summits in the Alaska Range and Talkeetna Mountains (see white areas on fig. 1), collectively occupy 11 percent of the Susitna River Basin. The Susitna River B asin has an average annual precipitation of 35 in., with local values exceeding 100 in. at higher elevations (Gibson, 2009a). B asin air temperatures average $29^{\circ} \mathrm{F}$ annually (Gibson, 2009b) and generally remain below freezing for the winter season of October-April.

Developed areas in the basin include the small towns of Willow and Talkeetna, together supporting a population of several thousand, and numerous small settlements mostly dispersed along the Parks Highway, the only major paved road through the area. The unpaved Denali Highway traverses a highland between the Alaska Range and the Talkeetna
Mountains and supports small settlements. Land ownership in the Susitna River Basin is primarily state and federal, including parts of Denali National Park and Preserve and Denali State Park, but includes corridors of Alaska Native lands al ong the Susitna River near the proposed dam site and private lands along the highway corridor and Susitna lowland. The Susitna River Basin supports five species of Pacific salmon that drive commercial, sport, personal use, and subsistence fisheries.

\section{Basin Characteristics}

The Susitna River ranks 15th in the nation by discharge, al though not by drainage area or length (K ammerer, 1990). The largest tributaries to the Susitna River - the Yentna, Chulitna, and Talkeetna Rivers - as well as the Skwentna River, a tributary to the Yentna River, are large streams that drain basins of at least 2,000 $\mathrm{mi}^{2}$ (table 1). The drainage areas of other gaged streams in the basin, the M aclaren and Deshka Rivers, and Montana, Willow, and Deception Creeks, range from about 50 to $600 \mathrm{mi}^{2}$. Glaciers are abundant (10-27 percent of basin area) in seven of the study basins, present in smaller amounts (5-7 percent of basin area) in four of the basins, and absent in four of the basins.

Table 1. Basin characteristics for selected streams in and near the Susitna River Basin, Alaska.

[Streamgage locations are shown in figure 1. Abbreviations: $\mathrm{ft}$, foot; in., inch; $\mathrm{mi}^{2}$, square mile]

\begin{tabular}{llcccccc}
\hline \multicolumn{1}{c}{ Streamgage name } & \multicolumn{1}{c}{$\begin{array}{c}\text { Map } \\
\text { identifier }\end{array}$} & $\begin{array}{c}\text { USGS station } \\
\text { identification } \\
\text { No. }\end{array}$ & $\begin{array}{c}\text { Drainage } \\
\text { area } \\
\text { (mi2) }\end{array}$ & $\begin{array}{c}\text { Mean basin } \\
\text { elevation } \\
\text { (ft) }\end{array}$ & $\begin{array}{c}\text { Lakes and } \\
\text { ponds } \\
\text { (percent) }\end{array}$ & $\begin{array}{c}\text { Glaciers } \\
\text { (percent) }\end{array}$ & $\begin{array}{c}\text { Mean annual } \\
\text { precipitation } \\
\text { (in.) }\end{array}$ \\
\hline Little Susitna River near Palmer, Alaska & LSu & 15290000 & 61.9 & 3,700 & 0 & 5 & 50 \\
Susitna River near Denali, A laska & SuDen & 15291000 & 950 & 4,510 & 1 & 25 & 50 \\
Maclaren River near Paxson, Alaska & M ac & 15291200 & 280 & 4,520 & 1 & 19 & 50 \\
Susitna River near Cantwell, Alaska & SuCant & 15291500 & 4,140 & 3,560 & 2 & 7 & 30 \\
Susitna River at Gold Creek, A laska & SuGold & 15292000 & 6,160 & 3,420 & 1 & 5 & 30 \\
Chulitna River near Talkeetna, A laska & Chul & 15292400 & 2,570 & 3,760 & 1 & 27 & 55 \\
Talkeetna River near Talkeetna, A laska & Talk & 15292700 & 2,000 & 3,630 & 0 & 7 & 35 \\
Susitna River at Sunshine, A laska & SuSun & 15292780 & 11,100 & 3,480 & 2 & 10 & 35 \\
M ontana Creek near M ontana, A laska & M ont & 15292800 & 164 & 1,930 & 3 & 0 & 30 \\
Willow Creek near Willow, Alaska & Will & 15294005 & 166 & 2,890 & 1 & 0 & 30 \\
Deception Creek near Willow, Alaska & Decep & 15294010 & 48 & 1,310 & 2 & 0 & 30 \\
Deshka River near Willow, Alaska & Desh & 15294100 & 591 & 492 & 5 & 0 & 25 \\
Skwentna River near Skwentna, Alaska & Skw & 15294300 & 2,250 & 2,810 & 5 & 16 & 45 \\
Yentna River near Susitna Station, Alaska & Yent & 15294345 & 6,180 & 2,730 & 1 & 15 & 50 \\
Susitna River at Susitna Station, Alaska & SuSta & 15294350 & 19,400 & 3,200 & 2 & 11 & 35 \\
\hline
\end{tabular}




\section{Streamflow in the Susitna River Basin}

\section{Streamflow Data}

As of 2010, the network of USGS streamgages with daily streamflow records contained 14 stations in the Susitna River Basin and 1 streamgage adjacent to the basin, the Little Susitna River near Palmer, whose record showed streamflow characteristics similar to some streams in the basin. (fig. 1). The present dam licensing process prompted resumption of gaging at several previously discontinued stations and the installation of two additional streamgages in the basin in 2011 but these additional records are not included in this study.

The Susitna River Basin streamgaging network began with the installation of a streamgage on the Susitna River at Gold Creek in A ugust 1949, and consisted of seven streamgages by 1964. An extensive study of the hydropower potential of the Susitna River brought the total number of concurrently active streamgages in the basin to a maximum of 13 in 1982. W hen the study ended in 1986, streamgaging ceased at two-thirds of the streamgages in operation in the basin at the time, but records of at least 5 years had been obtained at all streamgages. A 14th streamgage was installed in 2005.

The streamflow data collected in the Susitna River Basin enabled designation of two streamgages as primary potential index stations: Susitna River at Gold Creek, operated since August 1949 but discontinued between 1997 and 2001, and Talkeetna River near Talkeetna, which was installed in June 1964 and has since been operated continuously. The other stations on the Susitna River and its tributaries constitute potential secondary index stations for shorter periods. Although the Little Susitna River near Palmer streamgage is outside the Susitna River B asin (fig. 1), it records streamflow from a similar setting in the Tal keetna M ountains and has an unbroken record since water year 1949, making it an additional potential index station. None of the 14 gaged Susitna River B asin streams have been regulated or subjected to broad-scale land-use change, ensuring that streamflow reflects natural conditions at all sites.

\section{Streamflow Patterns}

Daily discharge in many large nested or neighboring Susitna River B asin streams corresponded closely, and any lags in flow between nested sites along the Susitna River did not appear to affect correlation of daily discharge. Large streams generally owe their flow patterns to basin-wide conditions, such that daily flow at neighboring or nested streamgages is likely driven by the same regional climatic conditions and precipitation events.

Annual streamflow patterns in the Susitna River Basin are driven by the relative timing and magnitude of glacier melt, snowmelt, and rainfall. Plots of mean daily discharge for the observed period of record helped place Susitna River $B$ asin streamgages into four groups along a continuum of these streamflow drivers (fig. 3). Mean daily discharge was computed as the mean of all daily mean values occurring on that calendar day for the chosen period. February 29 commonly shows an anomalous spike because that date occurs less often in the record. For the purposes of comparison, figure 3 shows the mean daily discharge for a 4 -year period, WY 1982-1985, which was common to all study streams except Montana Creek and Skwentna River, for which an alternative period was used.

All study streams have a winter period of declining flows (November or December through March or April). Breakup occurs in the spring, when stream ice cover melts and discharge begins to increase abruptly with the contribution of snowmelt. In the Susitna River Basin, breakup occurs in A pril or early May. Streams with a defined snowmelt peak attain that peak in the period May to mid-June. Glacier melt reaches a maximum rate later in the summer than snowmelt, such that Susitna River Basin streams whose flow is dominated by glacier melt have higher mean flows in July than in June (fig. 3A). No decrease following snowmelt is discernible for these streams. 
Instead, mean daily discharge continues to increase until a glacier-melt peak is reached. The flow of several Susitna River Basin streams shows traits from both glacier and snowmelt contributions (fig. 3B). The percentage of basin glacier cover alone could not explain the shift toward higher snowmelt-driven streamflows than glacier-melt-driven streamflows. Streams with higher glacier-melt-driven flows (fig. 3A) had a basin glacier cover of at least 10 percent, but two streams whose basins have more than 15 percent glacier cover had higher snowmelt-driven flows (fig. 3B). Flow in the lowest elevation streams (fig. 3D) reaches a snowmelt peak, decreases farther than for snowmeltdriven streams (fig. $3 \mathrm{C}$ ), then may remain steady or increase during the summer and autumn in response to rainfall runoff.
The most well documented influence on longer-term patterns in streamflow in the Susitna River Basin is the PDO, a multi-decadal pattern in North Pacific sea surface temperature variability that has been shown to have an effect on precipitation and air temperature in A laska (Hartmann and Wendler, 2005). During the warm phase of the PDO, sea surface temperatures in the Gulf of Alaska are warmer (Mantua and others, 1997) and air temperatures and precipitation tend to be higher across most of A laska (H artmann and Wendler, 2005) than in the cool phase. Monthly PDO index values, defined as the leading principal component of North Pacific monthly sea surface temperature variability, were obtained from the University of Washington

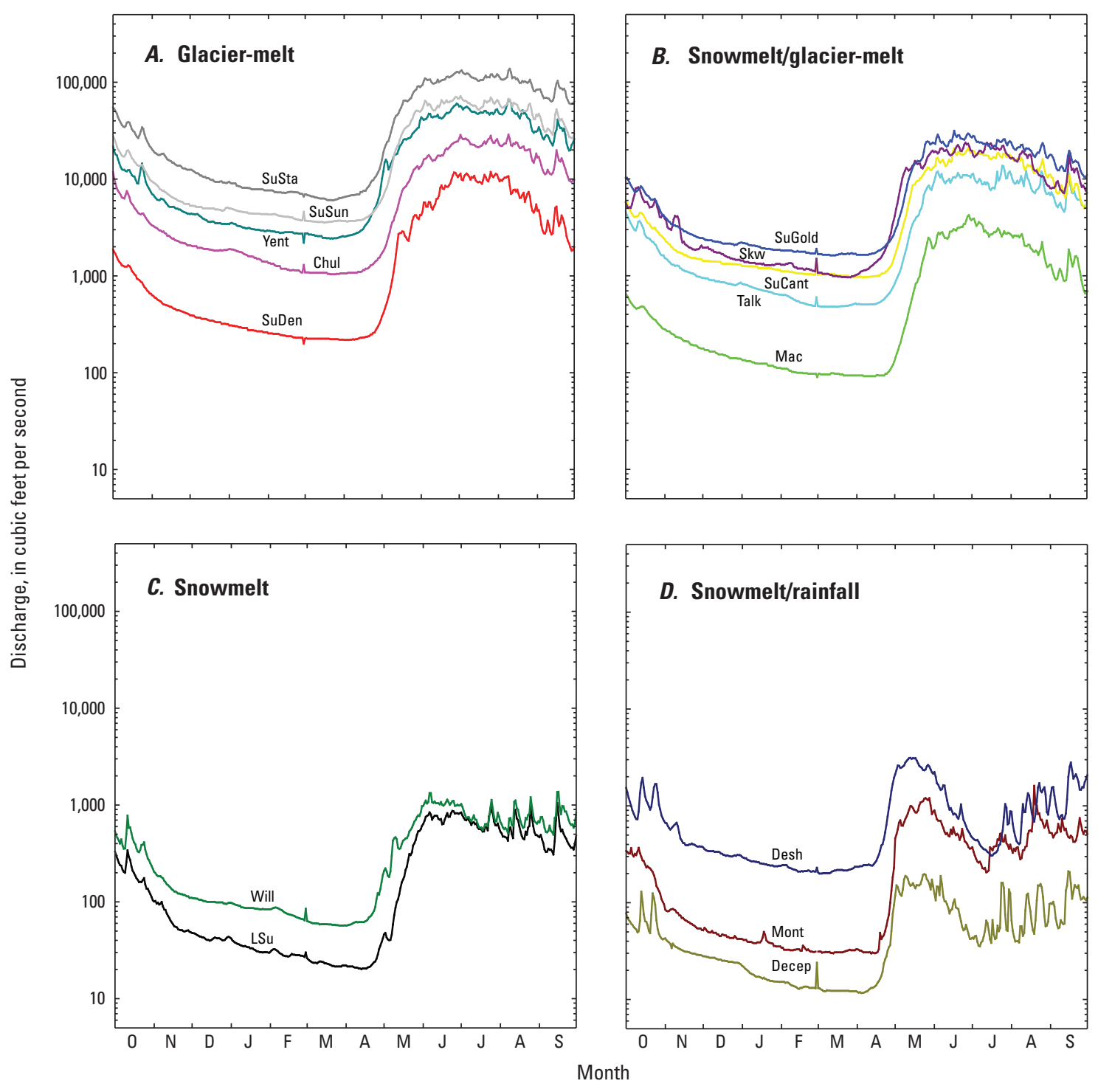

Figure 3. Mean daily discharge for selected streamgages in and near the Susitna River Basin, Alaska, categorized by relative contribution of glacier melt, snowmelt, and rainfall. Values are the mean of all daily discharge values for each calendar day of a 4-year period (water years 1982-1985) for all streamgages except those on Montana Creek (water years 2005-2010, including partial years), and Skwentna River (water years 1979-1982). Locations, full station names, numbers, and map identifiers are shown in figure 1. 
Joint Institute of the Atmosphere and Ocean (2012) for 1920-2011 and plotted (fig. 4) to help define warm and cool periods when the index was predominantly positive and negative, respectively. Researchers have delineated al ternating warm and cool PDO phases, each persisting for two to three decades but including short periods of the opposite-signed index. The year-to-year fluctuations in the index make defining boundaries difficult, especially for a recent phase shift. Although many researchers recognize a phase shift in the PDO in 1976, the ending date for the recent warm phase varies. For computations in this study, the most recent cool phase was defined as 1947-1976 and the most recent warm phase was defined as 1977-2007.

Studies linking Alaska streamflow to the PDO determined that, compared to flows during the most recent cool phase of the PDO, flows during the most recent warm phase were higher in winter, particularly for glaciated basins (Neal and others, 2002; Hodgkins, 2009). In summer, streamflows during the most recent warm phase were higher for glaciated basins and lower for nonglaciated basins. On average, mean annual discharge was not significantly different between PDO phases in Southeast Alaska (Neal and others, 2002). However, Hodgkins (2009) determined a slight increase in mean annual discharge statewide during the warm phase (Hodgkins, 2009). For the Susitna River at Gold Creek, Hodgkins (2009) reported minimal changes in mean annual discharge (1 percent greater during warm phase), appreciable increases in winter (October-April) mean monthly discharge (19-50 percent higher during warm phase), and a slight decrease in summer (June-August) discharge (1 percent higher to 8 percent lower during warm phase).

A plot of mean daily discharge in the warm phase (1977-2007) relative to flows in the cool phase (truncated to $1950-1976$ to match the study period) of the PDO for the primary index stations in and near the Susitna River Basin shows an increase in flows during winter and an earlier and slightly smaller snowmelt peak (fig. 5) during the warm phase. The variability in flows during the rest of the summer season is smaller and less well defined. Freeze-up, although not as dramatic as breakup, occurs during the autumn decrease in streamflow and shifts to later in autumn during the warm phase.

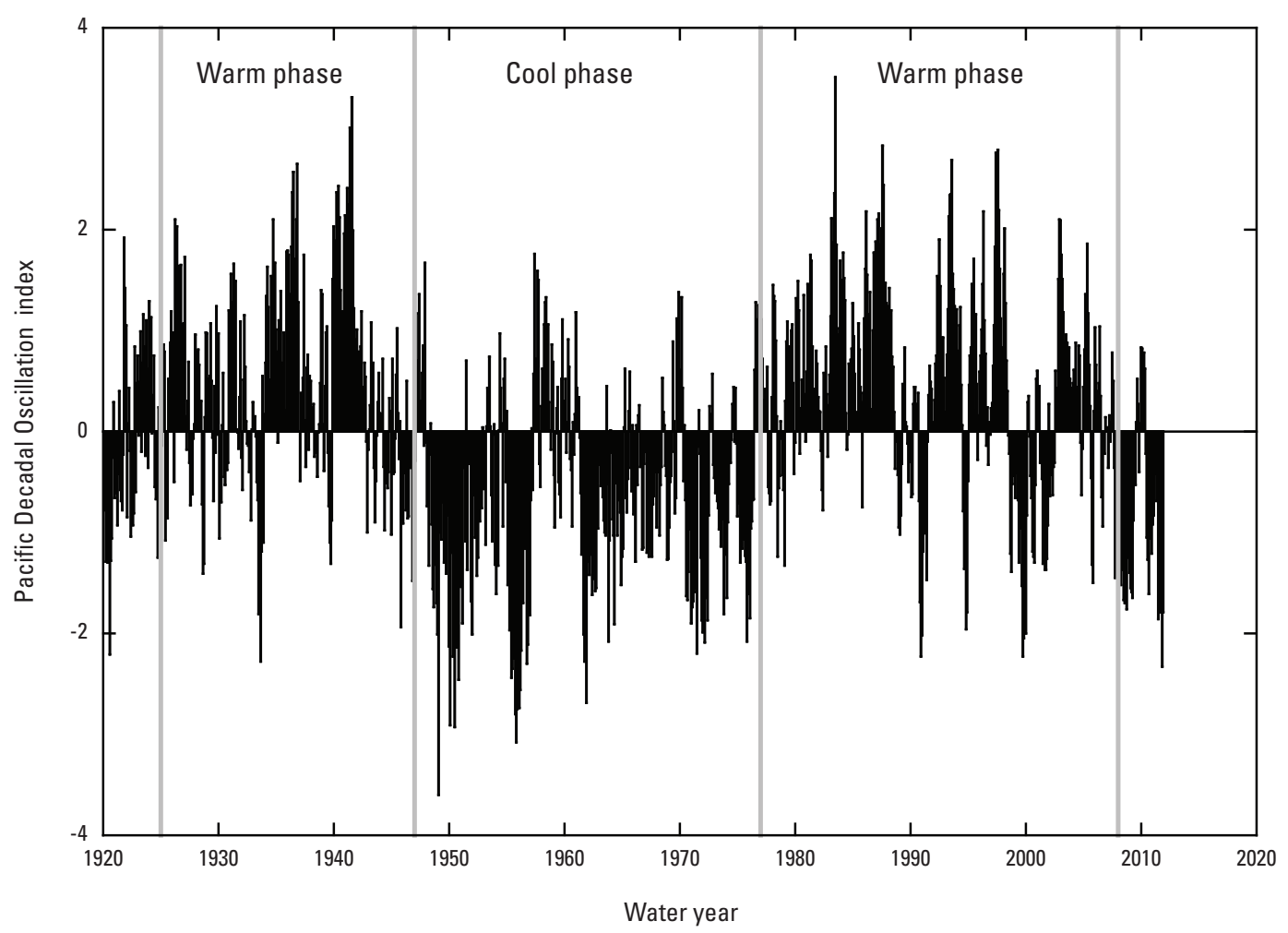

Figure 4. Index values and phase shifts in the Pacific Decadal Oscillation, 1920-2011. Index values were obtained June 5, 2012 (University of Washington Joint Institute for the Study of the Atmosphere and Ocean, 2012). 


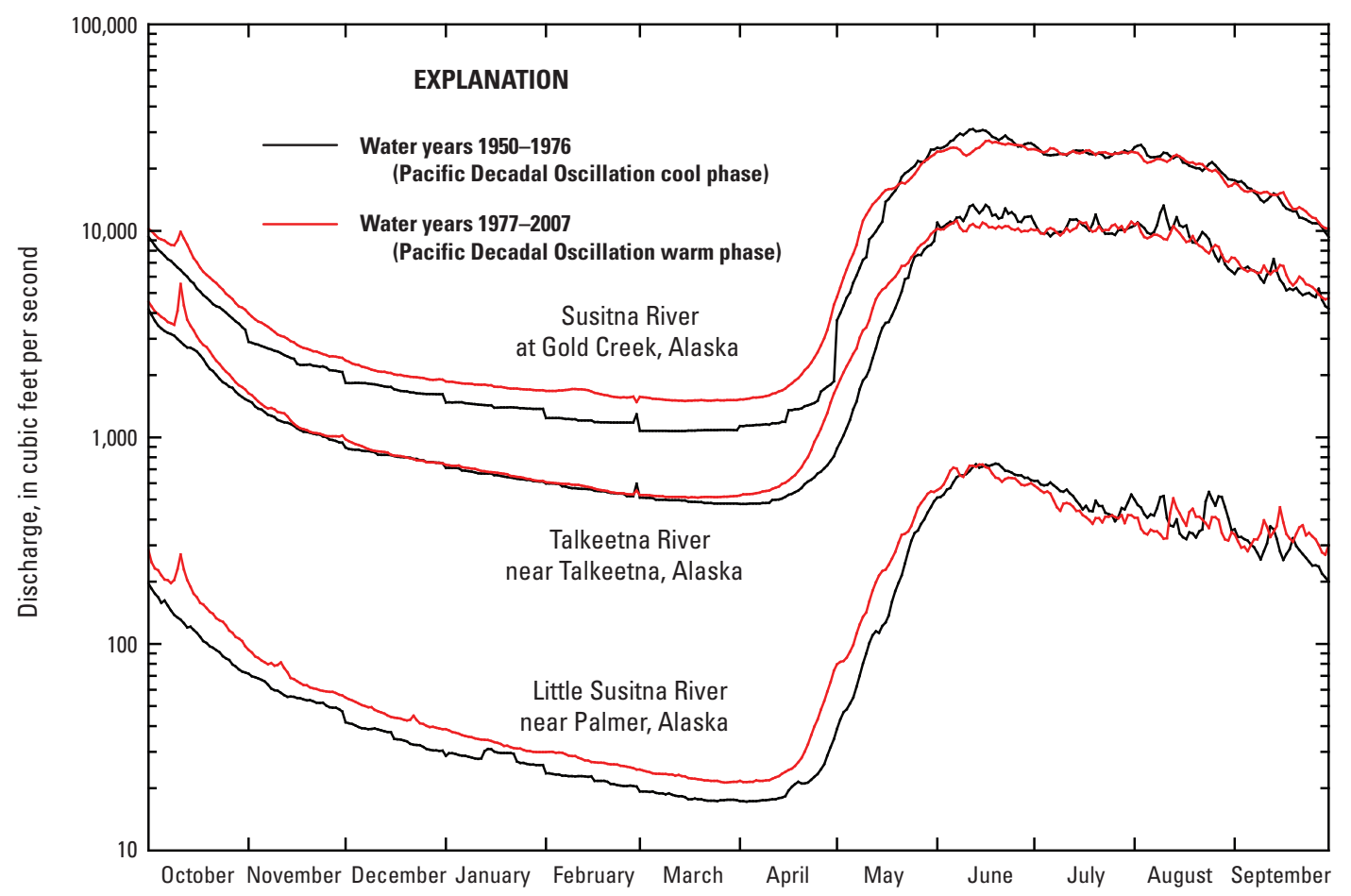

Figure 5. Variability in mean daily discharge during the most recent cool phase and warm phase of the Pacific Decadal Oscillation for primary index stations in and near the Susitna River Basin, Alaska. The cool phase began in 1947, but the study period began in water year 1950. The period of record shown is water years 1950-96, 2001-10, (Susitna River at Gold Creek), water years 1964-2010 (Talkeetna River near Talkeetna), and water years 1950-2010 (Little Susitna River near Palmer). Locations, full station names, numbers, and map identifiers are shown in figure 1.

\section{Methods of Analysis}

\section{Selection of Period of Analysis}

The period selected for analysis extended from WY 1950, the first full water year of data collection for the primary index station Susitna River at Gold Creek, to the end of WY 2010. A few months of data prior to October 1, 1949, are available for the Susitna River at Gold Creek, and flow data for the Little Susitna River near Palmer begins on July 1, 1948, but the study period was set to coincide with the start of WY 1950 for convenience of computing monthly statistics and consistency between extended records.

\section{Data Review}

Observed discharge data for USGS streamgages are available online through the National Water Information System (NWIS; U.S. Geological Survey, 2012). Although all data used in this study are published final values, annual hydrographs were inspected for potential anomalies that might limit streamgage suitability as an index station. Hydrographs for the Susitna River at Gold Creek for 1954, 1956, 1958, and 1961 through 1963 display a stepped pattern consisting of values that remain constant for a period of weeks, but then jump to a new, constant value. Although Alaska USGS streamflow records prior to the 1980 s do not contain a code to indicate data quality, this pattern is typical of periods when discharge must be estimated because of equipment failure, the presence of ice, or other reasons. The Susitna River at Gold Creek was the primary index station for this study and was the only index station available prior to 1958 with the exception of the Little Susitna River near Palmer, which was suitable as an index station for only one stream. No alternatives to the Susitna River at Gold Creek were available for the estimated periods in 1954 and 1956, but other Susitna R iver streamgages near Denali and near Cantwell were considered as index stations for the 1958 and 1961-63 estimated periods. The values estimated for Susitna River at Gold Creek followed the general trends in flow at the possible alternative index stations as well as the general trends in other years of Susitna River at Gold Creek record, so no substitutions were made. 
The inspection of the hydrographs suggested that al though daily variations in discharge were not captured during these estimated periods, mean monthly values are likely to be of good quality.

Winter streamflow conditions for all sites in this study include periods of ice cover. Ice-affected discharge must be estimated and is indicated as such in the gaging record. A lthough USGS streamgaging practices aim to constrain these values as closely as possible, estimated winter values could not be used as confidently as open-water season values for comparing the performance of the various equations used in the extension of streamflow records.

In 1964, the Susitna River at the three streamgages then operating (Susitna River near Denali, near Cantwell, and at Gold Creek) displayed an unusual pattern consisting of a high snowmelt peak in early June, followed by a steady decrease. A lthough the Tal keetna River streamgage did not begin operating until June 1, 1964, the partial record available for summer 1964 displays a similar pattern. The similarity in patterns across all available streamgages suggests this unusual pattern was related to basin-wide conditions, making it suitable for use in estimating flows at other stations.

\section{Selection of Index Stations}

For each site of interest, one or more potential index stations were selected on the basis of strength of correlation of daily values, hydrologic similarity, length of concurrent record, and length of extension possible. Log-scale scatterplots of concurrent daily records (appendix A) were visually examined for tightness of fit and extent of outliers, and log-scale plots of mean daily discharge for the period of record (similar to figure 3) were examined for similarities in seasonality and streamflow drivers. Pearson's correlation coefficients ( $r$ ) were computed for the logarithms of daily discharge at all combinations of potential index stations and sites of interest (table 2). Inspection of the various plots and statistical metrics showed that a minimum $r$ of 0.95 produced the best matches. Spearman's correlation coefficients, a nonparametric statistic that can measure dependence even when the fit is not linear (when very low flows or very high flows have a different fit than mid-range flows, for example), was computed but did not vary enough from $r$ to alter the selection of index stations.

The length of concurrent record for adequately correlated sites was at least 5 years for all sites except for Skwentna River near Skwentna and Yentna River near Susitna Station, which overlapped for only 2 years, but are nested sites with many similar basin characteristics. Sites were considered as index stations only if they provided at least 3 years of record extension for the site of interest. Extending a record for shorter lengths of time was technically feasible, but the increased number of computations needed to compute and review estimates from an additional index station outweighed the benefit of improving 1-2 years of a record.

In addition to the primary index stations (Susitna River at Gold C reek and Tal keetna River near Talkeetna), as many as three additional potential index stations that met the minimum requirements were considered for each site of interest by ranking correlation coefficients. Typically, one or two correlation coefficients were notably larger than the others so that selection of an index station was straightforward. When several correlation coefficients were similar, priority was given to the closest sites and to sites on the same stream. The sites meeting these screening requirements formed the initial suite of index stations for computation of predicted values and evaluation of fit of predicted to observed values.

Table 2. Correlation coefficients (Pearson's $r$ ) between logarithms of daily discharge values at sites of interest and potential index stations for streams in the Susitna River Basin, Alaska.

[Shading indicates values equal to or greater than 0.950. LSu, Little Susitna River near Palmer, Alaska. -, index station not suitable because length of potential extension or overlap is inadequate]

\begin{tabular}{|c|c|c|c|c|c|c|c|c|c|c|c|c|c|c|c|c|}
\hline \multirow{2}{*}{ Streamgage name } & \multirow{2}{*}{$\begin{array}{c}\text { Map } \\
\text { identifier }\end{array}$} & \multicolumn{15}{|c|}{ Potential index station } \\
\hline & & LSu & SuDen & Mac & SuCant & SuGold & Chul & Talk & SuSun & Mont & Will & Dec & Desh & Skw & Yent & SuSta \\
\hline ssitna Rive & & 0.928 & - & - & - & 59 & - & 0.957 & - & - & 0.892 & - & - & - & - & 0.963 \\
\hline Susitna River near Cantwell, Alaska & SuCant & 0.941 & 0.971 & 0.970 & - & 0.986 & - & 0.965 & - & - & 0.930 & - & - & 0.957 & - & 0.970 \\
\hline $\mathrm{ka}$ & SuGold & 0.946 & - & - & - & - & - & 0.968 & - & - & - & - & - & - & - & - \\
\hline Chulitna River near Talkeetna, A laska & Chul & 0.954 & 0.970 & 0.964 & - & 0.969 & - & 0.976 & - & - & 0.930 & - & - & 0.967 & - & 0.972 \\
\hline M ontana Creek near M ontana, A laska & Mont & 0.916 & - & - & - & 0.919 & - & 0.931 & - & - & 0.963 & - & - & - & - & - \\
\hline Willow Creek near Willow, Alaska & Will & 0.959 & 0.892 & 0.890 & & 0.922 & 0.930 & 0.938 & - & - & - & - & - & - & - & - \\
\hline Deception Creek near Willow, Alaska & $\mathrm{Dec}$ & 0.678 & 0.602 & 0.606 & 0.732 & 0.673 & 0.702 & 0.702 & - & - & 0.799 & - & - & - & - & 0.713 \\
\hline Deshka River near Willow, Alaska & Desh & 0.549 & 0.507 & 0.506 & 0.602 & 0.594 & 0.574 & 0.585 & - & - & 0.677 & - & - & - & - & 0.650 \\
\hline Skwentna River near Skwentna, Alaska & Skw & 0.934 & - & - & - & 0.956 & - & 0.952 & - & - & 0.922 & - & - & - & 0.989 & 0.974 \\
\hline & & 0.933 & 0.957 & 0.951 & 0.962 & 0.967 & 0.956 & 0.956 & - & - & 0.920 & - & - & 0.989 & - & 0.987 \\
\hline
\end{tabular}




\section{Record Extension Techniques}

Quantitative methods for estimating daily discharge values at a site of interest on the basis of daily discharge values at an index station generally employ some form of linear regression, but each approach has slight variations that provide an advantage for a particular application. The line of organic correlation provides a more suitable method for streamflow record extension than ordinary least squares or least normal squares (Helsel and Hirsch, 2002). Also known as $M$ aintenance of Variance-Extension (M OVE), the technique provides a means to retain the long-term variance of the index station data. The $K$ endall-Theil R obust $L$ ine (KTRL) method is a nonparametric technique, providing an advantage where outliers are present (Helsel and Hirsch, 2002). Two MOVE methods, M OVE.1 (Hirsch, 1982) and M OVE.3 (Vogel and Stedinger, 1985), and the nonparametric KTRL method were selected as suitable for use with the Susitna River Basin data. Criteria for selection of a particular method for this study included the theoretical applicability of the method, suitability of the data given the requirements of the method, and ease of computation.

Streamflow record extension computations are performed on the logarithms of daily discharge values; results are then retransformed to obtain estimated daily discharge. The general form for a daily discharge regression equation is based on the equation for a straight line using the logarithms of discharge,

where

$$
Y_{i}=m X_{i}+b+e_{i}
$$

$Y_{i}$ is the logarithm of the discharge value for the $i$ th day at the site of interest,

$m$ is the slope of the regression line,

$X_{i}$ is the logarithm of the discharge value for the $i$ th day at the index station,

$b$ is the intercept of the regression line, and

$e_{i}$ is the residual error (the difference between $Y_{i}$ and the regression-line estimate for the $i$ th day.

The estimated discharge values are then obtained as $10^{\gamma_{i}}$.

M OVE. 1 is a parametric method that calculates the slope $(m)$ as the product of the sign of the correlation coefficient $(r)$ and the ratio of the standard deviations of the $Y$ values and concurrent $X$ values. The intercept (b) is calculated so that the line passes through the mean of the $X$ and $Y$ populations.

MOVE. 3 is a variation of the M OVE method that captures statistics from the full length of available record. M OVE. 3 uses estimates of the mean and standard deviation for the concurrent period from both stations but also incorporates the mean and standard deviation for the nonconcurrent period from the index station.
The KTRL method, as a nonparametric technique, avoids use of the mean and instead estimates the slope $(\mathrm{m})$ as the median of all pairwise slopes between each pair of points in the data set (Theil, 1950; Sen, 1968). The intercept (b) is calculated so that the line passes through the median of the $X$ and $Y$ populations (Conover, 1980).

R egardless of the method used, a multi-segment line can improve fit when particularly high or low flows have a different correlation to index station values than do mid-range flows. A model is constructed from two or more straight-line segments, each applicable to a range of flow magnitudes. A dditionally, independent estimates from multiple index stations can be combined to improve the overall estimate.

The USGS has developed a suite of software to facilitate the use of MOVE and KTRL equations. The Streamflow Record Extension Facilitator (SREF) program (Granato, 2009) fits MOVE. 1 and MOVE. 3 equations to data for one or more index stations, computes estimated values for the site of interest using each index station individually, and then provides a method for weighting values for multiple index stations. This program does not automate the computation of multiple line segments for a single index station. The KTRL ine program (Granato, 2006) provides a graphical interface that assists the user in selection of breakpoints for multiple line segments for a single index station. The KTRL equations computed for each line in the multi-segment model are then entered in the SREF program for computation of the estimated values. Weighting values from multiple stations must be done manually.

For the Susitna River B asin data, log-scale scatterplots of daily values for each site of interest against each prospective index station (appendix A) were inspected for patterns that would require a particular method of analysis. A first-degree-polynomial locally-weighted scatterplot smoothing (LOWESS) curve fitted to the scatterplot revealed a generally good fit of a straight line to the bulk of the data. The largest and most frequent outliers, or points falling far from the densest concentration of points, occurred in the mid-range values. Inspection of dates of occurrence suggested these outliers occurred during the spring snowmelt period when one river began breakup before the other. Outliers at very high flows also were common, typically as sparse, scattered groups of values rather than outstanding single values. For most site pairs, a slight to moderately pronounced bending of the curve at very high flows, very low flows, or both suggested that a better fit could be obtained from multiple straight-line segments.

Application of all three methods to a few sites of interest helped narrow the choice of methods. Results of the solution of MOVE.1 and M OVE.3 equations varied extremely little relative to the difference between MOVE.1 and KTRL, and relative to the difference between the observed and predicted values. M OVE. 3 offered no considerable advantage and is a 
more theoretically complicated method than M OVE.1, so it was omitted from further consideration. The fit of MOVE.1 relative to KTRL was tested for one site where no multipleline segment was required, Willow Creek near Willow, and for a site where a multi-segment model was required by manually segregating the input data to SREF. For extending the record of Willow Creek near Willow with the data from Little Susitna River near Palmer, both equations produced acceptable results. The MOVE. 1 and KTRL lines passed through high-flow data at similar locations but diverged slightly at lower flows, with the result that MOVE.1 produced the more expected result of higher winter flows with additional years of record from the PDO warm phase. However, producing a multisegment M OVE.1 model in SREF required too much iteration involving extensive manual input data manipulation to converge on a solution with confidence. Multi-segment models with MOVE. 1 were impractical for the tens of station pairs required for this study.

A seasonal approach to developing equations was considered because daily discharge values clustered into generally expected seasonal groups on the scatterplots. However, the overall fit was comparable to that obtained by a multiple-line segment in KTRL and the amount of manual manipulation of input data was prohibitive for the seasonal analysis.

\section{Computing Record Extension Equations}

\section{Record Extension Equations for Individual Index Stations}

The multi-segment capacity of the KTRLine program provided a convenient method for computing regression equations for all station pairs in this study. A log transform, commonly applied to streamflow data, created a more linear fit to the data for all station pairs. When a multi-segment line appeared appropriate, breakpoints visually determined from the LOWESS-smoothed line on the log-scale scatter plot of daily discharge were entered into the KTRLine program and adjusted until improvements diminished. Iterations included the default 1-segment line, then several attempts at multi-segment lines, increasing the model one segment at a time until the best fit was obtained with the fewest possible segments. Resulting equations (table 3 ) contained a maximum of four segments. A $n$ overlay of each equation on the scatterpl ot of concurrent daily discharge (appendix A) shows the fit of the equation to the source data. Values from table 3 for each equation were entered into SREF, which computed the extended discharge values and retransformed them from logarithmic values to produce a suite of predicted (estimated values for the period concurrent with the index station) and extended (estimated values for the nonconcurrent period) daily discharge values for the site of interest.

\section{Weighting Multiple Index Stations}

If more than one index station was available for a particular subperiod, the fit of predicted values from the various stations singly and in combination compared to the observed values guided compilation of a final date-specific set of index stations. Index station selection also relied on a measure of fit termed the modified Nash-Sutcliffe efficiency (NSE). Alternative measures of model fit in hydrologic applications avoid the influence of extreme values and other issues with the more familiar correlation-based measures such as the coefficient of determination, $r^{2}$. The NSE suggested by Legates and M cCabe (1999) ranges from 1, indicating that the model perfectly predicts the observed data, to minus infinity, indicating the model has no predictive ability. An NSE of 0 indicates that the model is no better a predictor than the average of the observed data. The modified efficiency is computed as

$$
N S E=1-\frac{\sum_{i=1}^{n}\left|Y_{i}-Y_{p}\right|}{\sum_{i=1}^{n}\left|Y_{i}-\bar{Y}\right|}
$$

where

$n$ is the number of measurements,

$Y_{i}$ is the ith observed daily discharge value,

$Y_{p}$ is the predicted daily discharge value, and

$\bar{Y}$ is the average of the observed daily discharge values.

A second index station was added to the model when the addition improved NSE by at least 1 percentage point. The addition of a third index station was considered, but never improved NSE by enough over the improvement gained with two stations to warrant the added model complexity, such that no model used more than two index stations for any given time period.

Selection of index stations was always coupled with visual comparison of the hydrographs of observed and predicted data from each index station for WY 1980-86 (fig. 6), which was selected as a common period for which data were available at most sites. The fit of summer peak flows, including the general trend but more specifically focusing on fluctuations on a daily to weekly basis, provided a more attainable measure than the winter low flows.

The final extended streamflow record from the selected multiple stations was produced by weighting the extended discharge values from each index station by the respective mean square error (MSE). MSE was computed from the predicted compared to observed values by the KTRLine program. 


\section{Streamflow Record Extension for Selected Streams in the Susitna River Basin, Alaska}

Table 3. Values for variables, discharge input ranges, and measures of error for equations for estimating daily discharge from index station data at selected streamgages, Susitna River Basin, Alaska.

[Streamgage locations and map identifiers are shown in figure 1. Slope, Intercept, and Range of daily discharge input values: Values are logarithms of discharge in cubic feet per second. RM SE, root mean square error]

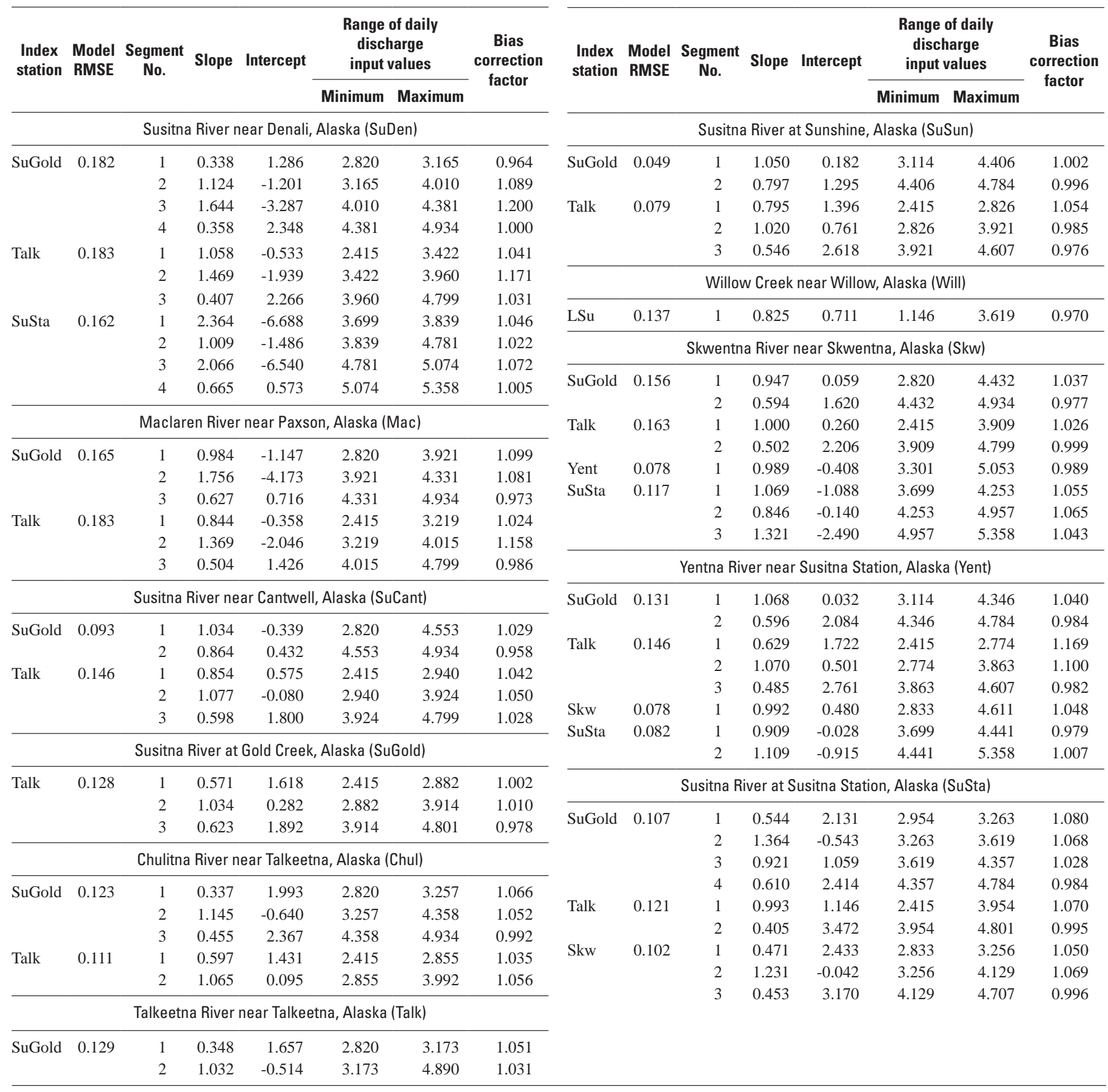



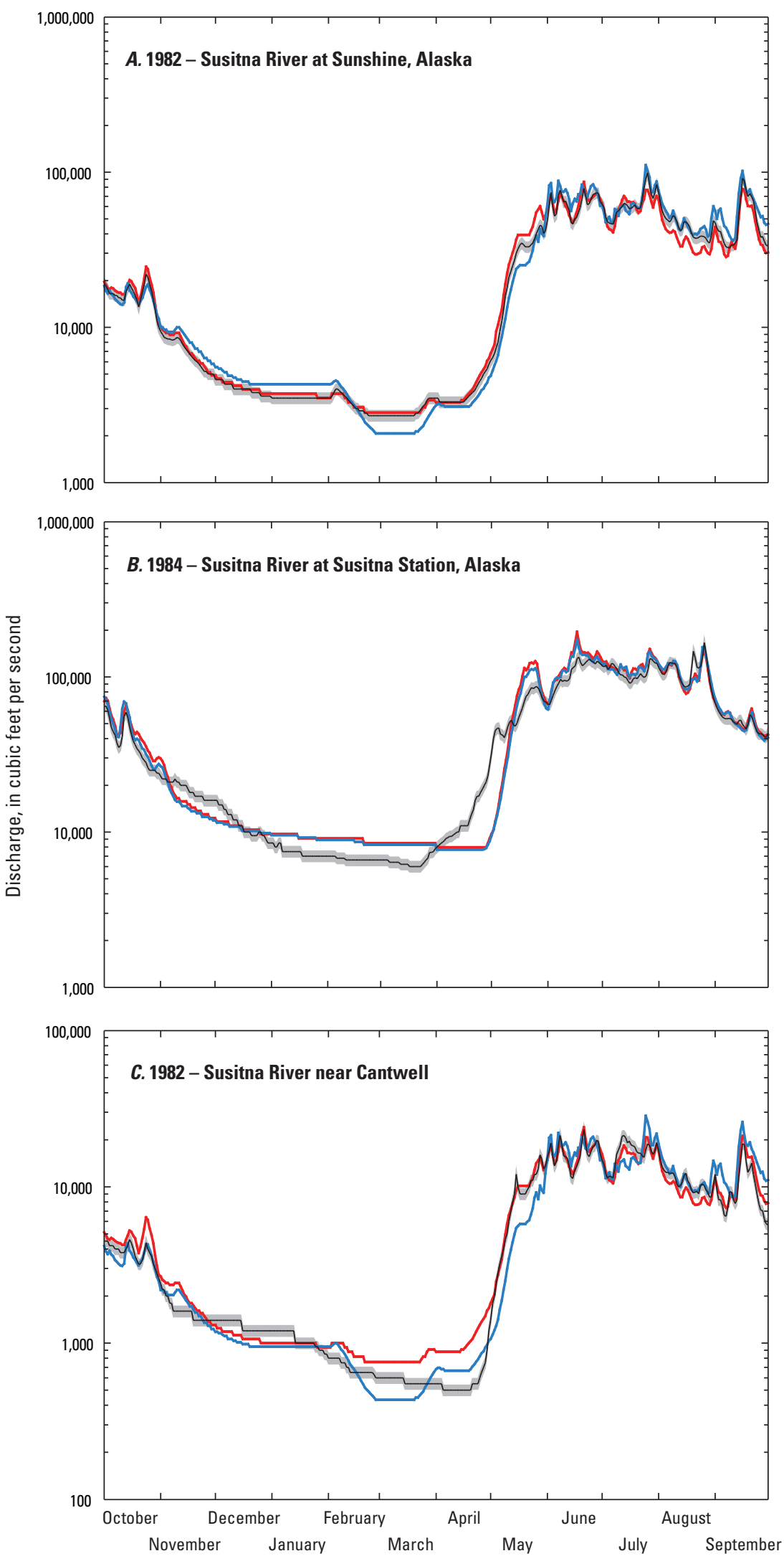

\section{EXPLANATION}

Mean daily discharge predicted by SuGold

Mean daily discharge predicted by Talk

Mean daily discharge observed

Range of mean daily discharge 8 percent greater than or less than observed value

Figure 6. Examples of predicted and observed discharge values for selected streamgages in the Susitna River Basin, Alaska. Predicted values are independent estimates of discharge at the site of interest based on records for index stations Susitna River at Gold Creek, Alaska (SuGold) and Talkeetna River near Talkeetna, Alaska (Talk), respectively. (A) Example of a good fit for two index stations. Final values were computed as a weighted estimate of values from both index stations. $(B)$ Example of poor fit during winter, breakup, and snowmelt periods. In this particular year, streams at the index stations were ice-covered longer than the site of interest. (C) Example of a better fit for one index station. The fit is reflected in the respective correlation coefficients (table 2, 0.986 for Susitna River at Gold Creek, Alaska and 0.965 for Talkeetna River near Talkeetna, Alaska). Locations, full station names, numbers, and map identifiers are shown in figure 1. 


\section{Extended Streamflow Records}

\section{Index Stations Used to Extend Streamflow}

Index stations were available to enable computation of extended streamflow records for WY 1950-2010 for 11 of the 14 streamgages in the Susitna River B asin. The streamgages on M ontana Creek, Deception Creek and the Deshka River were omitted from analysis because they could not be adequately correlated to any long-term index station for the entire study period (table 2). The daily patterns in these lower-elevation, snowmelt-and-rainfall-driven streams did not match the patterns of the available index stations, which had stronger influences from glacier melt and snowmelt.
L imited record availability dictated the selection of index stations in the early and late parts of the study period, and correlation and length of extension winnowed choices during the 1960-80s. Eight streamgages were used as index stations for at least one other station (ig. 7). Table 4 lists the dates and index stations used for each subperiod. Although as many as four index stations were available to extend records for a single site of interest, no more than two index stations were used for any single subperiod of record extension. Little Susitna River near Palmer served as an index station only for Willow Creek near Willow because an earlier breakup and stronger decrease in flow after snowmelt at the Little Susitna River created a lack of seasonal hydrologic similarity to otherwise reasonably correlated glacier-melt

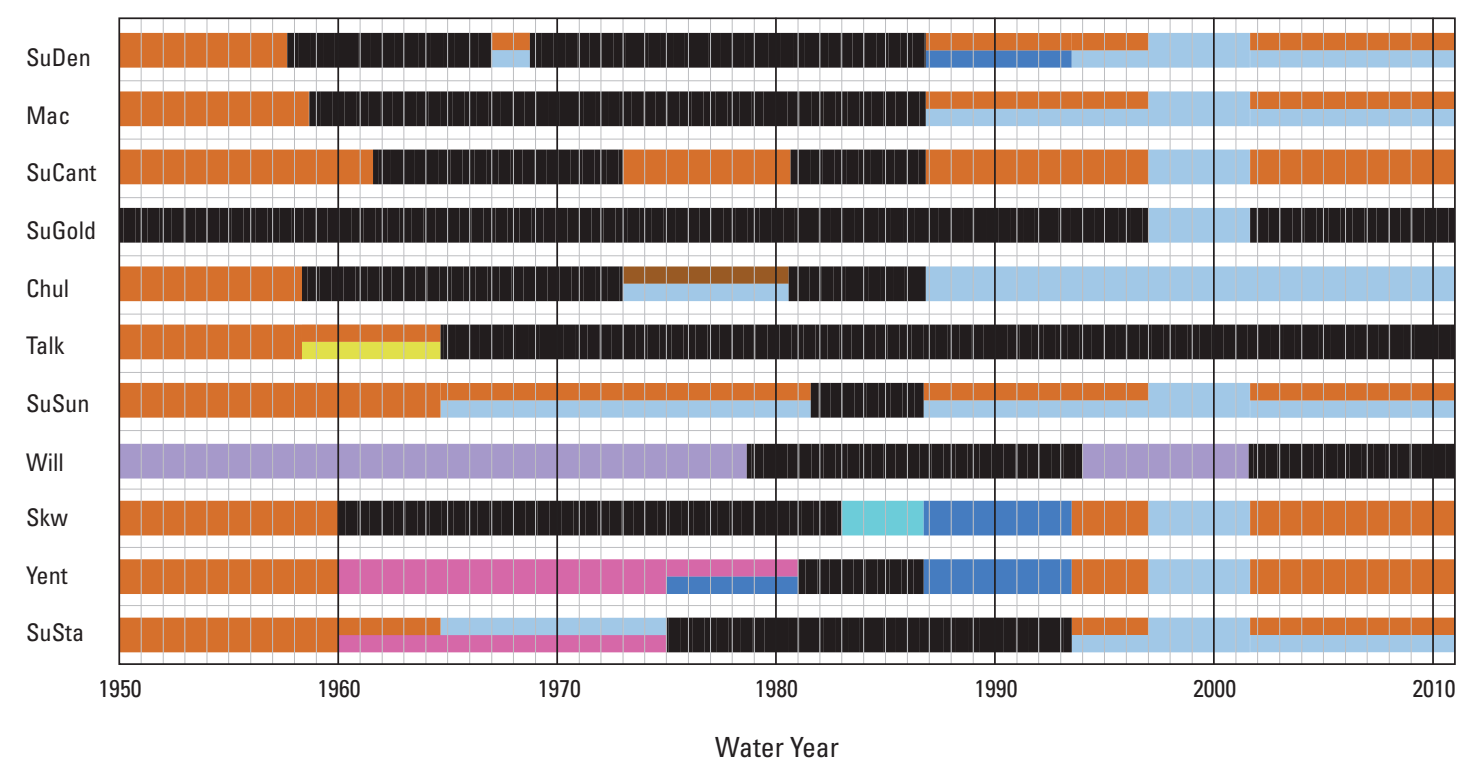

EXPLANATION

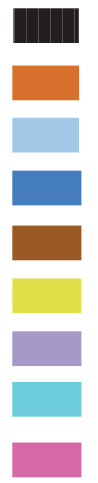

Observed data

Extended using SuGold as index station

Extended using Talk as index station

Extended using SuSta as index station

Extended using SuDen as index station

Extended using Chul as index station

Extended using LSu as index station

Extended using Yent as index station

Extended using Skw as index station

Figure 7. Index stations used to extend streamflow records in the Susitna River Basin, Alaska. Locations, full station names, numbers, and map identifiers are shown in figure 1. 
and snowmelt-driven sites. For all sites other than Willow Creek near Willow, Susitna River at Gold Creek served as the primary index station, partly because it had the only record available for many subperiods and partly because of good correlation of daily discharge values. For the period October 1, 1996, to May 24, 2001, when no record was available for the Susitna River at Gold Creek, the Talkeetna River near Talkeetna served as a substitute index station. The combination of Susitna River at Gold Creek and Talkeetna River near Talkeetna also was commonly used in record extensions because it matched streamflows better than either station individually. The record for the Susitna R iver at Susitna Station was used to extend the record for the Susitna River near Denali for their subperiod of overlap despite the distance between the sites because no closer sites offered a better correlation.

Table 4. Periods of observed and extended streamflow records and index stations used for record extension for selected streamgages, Susitna River Basin, Alaska.

[LSu, Little Susitna River near Palmer, Alaska. -, measured values available]

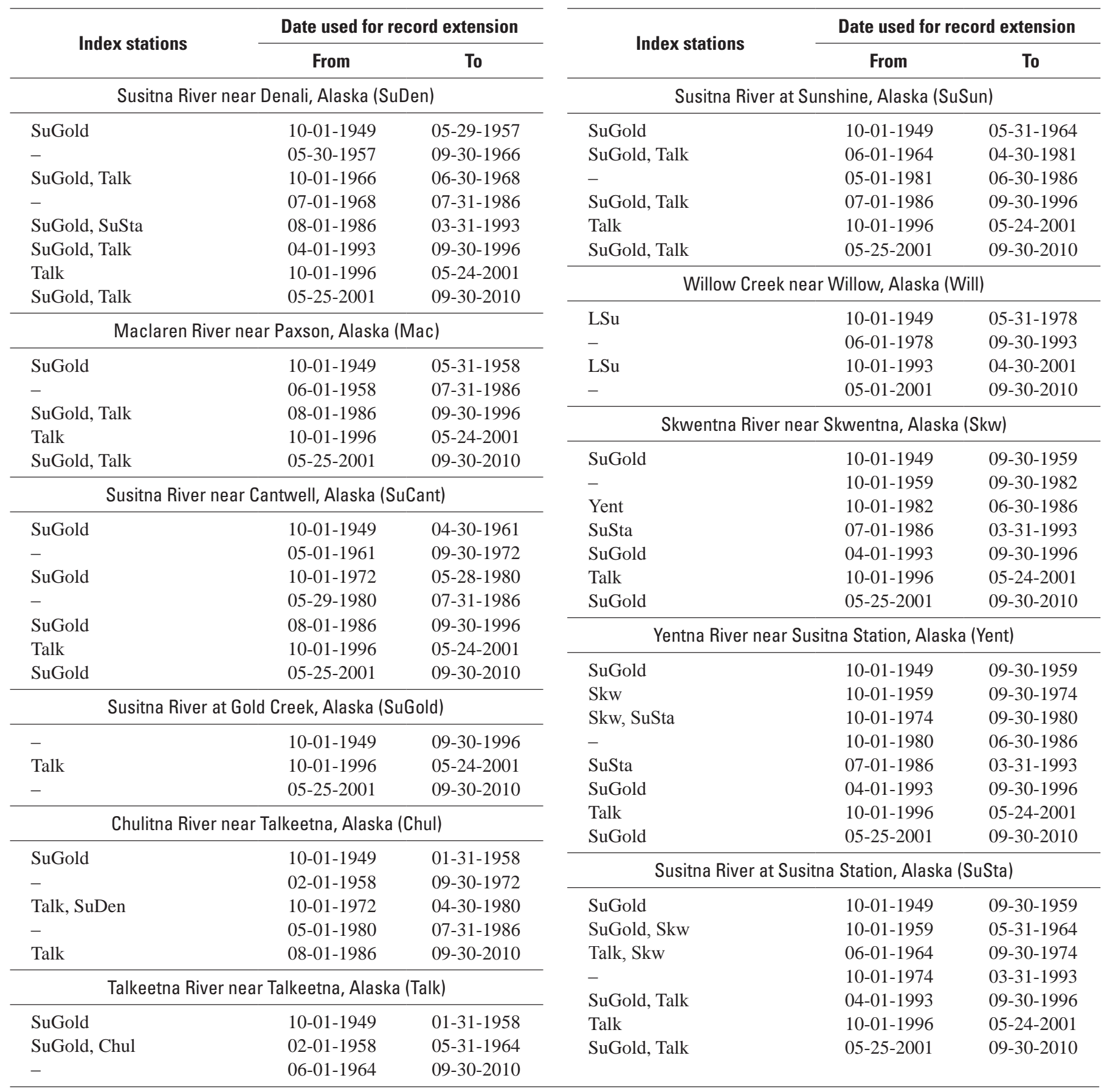




\section{Extended Record Data and Statistics}

Extended daily streamflow records for WY 1950-2010 that were computed for the 11 streamgages are presented in appendix B. The observed data available for the same period can be obtained from this file for convenience or from the NWIS website for the most current version. Extended-record data can be merged with data for observed periods to create a continuous composite record for WY 1950-2010.

The composite record of observed and extended values was compiled and used to compute monthly mean and annual statistics for the period WY 1950-2010. Mean monthly discharge for the composite record is presented in table 5 and the percent difference relative to the mean monthly discharge for all available years of the observed record is presented in table 6. A nnual mean discharge for the composite record for each year in the period WY 1950-2010 is shown in table 7. $M$ ean annual discharge, a long-term metric computed as the mean of all annual means for a given period, is shown for the composite record for WY 1950-2010 for each streamgage in table 8, which also shows the percent difference from the observed mean annual discharge.

\section{Differences Between Extended and Observed Records}

The difference in values between most composite (observed and extended) records for the study period and the available observed records in the study period followed the pattern expected from the amount of extended record relative to the length of the study period (table 6 , fig. 7) and the proportion of years added to the record from the PDO cool phase relative to the warm phase (fig. 2). Table 6 quantifies the differences by month, but plots of the mean daily discharge for the composite record for WY 1950-2010 compared to the available observed record during the same period (fig. 8) highlight the systematic differences in streamflow timing. Monthly discharge at stations whose records gained more PDO warm phase years than cool phase years during streamflow record extension (the Susitna River near Denali and near Cantwell, and the Maclaren River, Chulitna River, and Skwentna River streamgages) increased 7.9-46.3 percent in April and May as a result of earlier breakup. A corresponding delay in freeze-up and associated increased streamflows occurs during autumn (September or
October) for these stations. The reverse is true for stations whose records gained more PDO cool phase years than warm phase years during extension. M ean monthly discharge at the Yentna River near Susitna Station and at the Susitna River at Susitna Station decreased about 10 percent in A pril because of a delayed breakup relative to the observed record, and lower October flows corresponded to earlier freeze-up. The extended record for Willow Creek shows breakup beginning at about the same time as in the observed record, but the flow increases slower, resulting in a later snowmelt peak and a 25 percent decrease in mean $\mathrm{M}$ ay discharge. The extended record for the Susitna River at Sunshine gained more PDO cool phase years than warm phase years, which can account for the more than 15 percent decrease in monthly mean discharge in January-March, but breakup appears to be earlier at this site.

A lthough less prominent than the differences in spring streamflow values, the difference in summer values can be largely explained by the pattern of a lower snowmelt peak for extended records that gained mostly PDO warm phase years and a higher peak for those records that gained mostly PDO cool phase years. For glacier-melt dominated sites whose extended records gained PDO warm phase years, the lower flows persisted through June and July. For the glacier-melt dominated sites whose extended records gained PDO cool phase years, the greater flow was apparent only in June.

The period of extended record relative to the period of observed record for the two primary index stations, Susitna River at Gold Creek and Talkeetna River near Talkeetna, is much smaller than for the other streamgages in the basin (table 6). A s expected, shifts in the composited observed and extended record for these sites are minor, never exceeding a 5 percent difference in monthly mean discharge.

Record extension projects variations in the index station record onto the extended record for the site of interest, which governs the distribution of outliers. This is apparent in the minimum and maximum daily mean values for the Susitna River Basin sites. A large mid-February maximum value and a large October maximum value appear in many records as a result of record extension made on the basis of the data for the Susitna River at Gold Creek record. A nearly flat line in some winter maximum daily mean hydrographs appears as a result of extension using the Tal keetna River near Talkeetna record. A spike on February 29 is typically an artifact of the less frequent occurrence of that date, which reduces the potential for long-term averaging. 
Table 5. Mean monthly discharge for composite (observed and extended) records for selected streamgages in the Susitna River Basin, Alaska, water years 1950-2010.

[Streamgage locations and map identifiers are shown in figure 1]

\begin{tabular}{|c|c|c|c|c|c|c|c|c|c|c|c|c|}
\hline \multirow{2}{*}{ Streamgage name } & \multicolumn{12}{|c|}{ Mean observed and extended discharge for water years 1950-2010 (cubic feet per second) } \\
\hline & Oct. & Nov. & Dec. & Jan. & Feb. & Mar. & Apr. & May & June & July & Aug. & Sept. \\
\hline Susitna River near Denali, A laska & 1,332 & 503 & 326 & 263 & 229 & 212 & 293 & 3,124 & 7,402 & 8,584 & 7,305 & 3,639 \\
\hline Susitna River near Cantwell, Alaska & 3,798 & 1,601 & 1,126 & 938 & 820 & 755 & 1,032 & 8,629 & 16,860 & 15,840 & 13,910 & 8,625 \\
\hline Susitna River at Gold Creek, A laska & 6,319 & 2,672 & 1,893 & 1,593 & 1,420 & 1,303 & 1,743 & 13,790 & 26,290 & 23,990 & 21,430 & 13,770 \\
\hline Chulitna River near Talkeetna, A laska & 5,751 & 2,261 & 1,545 & 1,302 & 1,143 & 1,061 & 1,369 & 10,350 & 21,510 & 23,200 & 20,580 & 12,580 \\
\hline Willow Creek near Willow, Alaska & 332 & 153 & 105 & 84 & 71 & 60 & 79 & 487 & 1,043 & 745 & 666 & 573 \\
\hline Skwentna River near Skwentna, Alaska & 4,781 & 2,023 & 1,396 & 1,162 & 1,017 & 916 & 1,331 & 9,278 & 17,390 & 16,720 & 14,230 & 9,321 \\
\hline Yentna River near Susitna Station, Alaska & 13,400 & 5,349 & 3,642 & 3,021 & 2,655 & 2,402 & 3,484 & 26,940 & 50,640 & 49,870 & 43,070 & 27,940 \\
\hline Susitna River at Susitna Station, A laska & 36,000 & 14,390 & 9,513 & 7,909 & 7,082 & 6,512 & 8,995 & 66,060 & 120,000 & 121,600 & 109,000 & 72,810 \\
\hline
\end{tabular}

Table 6. Difference in mean monthly discharge between composite (observed and extended) records and observed records for selected streamgages in the Susitna River Basin, Alaska, water years 1950-2010.

[Streamgage locations and map identifiers are shown in figure 1. Difference in mean monthly discharge: Positive values indicate that the values in the composite record are greater than the values in the observed record only]

\begin{tabular}{|c|c|c|c|c|c|c|c|c|c|c|c|c|c|}
\hline \multirow{2}{*}{ Streamgage name } & \multicolumn{12}{|c|}{ Difference in mean monthly discharge (percent) } & \multirow{2}{*}{$\begin{array}{l}\text { Amount of composite } \\
\text { record consisting } \\
\text { of extended values } \\
\text { (percent) }\end{array}$} \\
\hline & Oct. & Nov. & Dec. & Jan. & Feb. & Mar. & Apr. & May & June & July & Aug. & Sept. & \\
\hline Susitna River near D enali, A laska & 12.8 & -4.2 & -3.8 & 0.2 & 3.9 & 6.4 & 25.8 & 46.3 & 1.7 & -12.7 & -10.5 & 10.4 & 55 \\
\hline Maclaren River near Paxson, Alaska & 10.5 & -5.2 & -3.8 & -2.9 & -1.6 & -1.2 & 18.7 & 34.4 & -3.3 & -10.0 & -5.1 & 13.4 & 54 \\
\hline Susitna River near Cantwell, Alaska & 12.9 & 1.7 & 0.8 & -2.4 & -1.2 & -3.1 & 12.8 & 9.1 & -7.5 & -9.7 & -6.8 & 8.7 & 71 \\
\hline Talkeetna River near Talkeetna, A laska & -3.7 & -3.2 & -2.3 & -1.7 & -1.6 & -1.2 & -4.7 & 1.4 & 0.8 & 1.1 & 1.1 & 1.4 & 24 \\
\hline Susitna River at Sunshine, A laska & -4.2 & -4.4 & -7.9 & -14.9 & -17.3 & -15.4 & 2.0 & 18.7 & 12.8 & -8.7 & -11.1 & -1.0 & 92 \\
\hline Willow Creek near Willow, Alaska & -22.2 & -3.2 & 0.0 & 0.2 & -2.3 & -1.3 & -17.5 & -25.4 & 6.3 & 17.0 & 7.8 & -9.5 & 59 \\
\hline Skwentna River near Skwentna, Alaska & 5.7 & 4.0 & 5.2 & 3.8 & 6.6 & 9.4 & 21.6 & 7.9 & -8.5 & -5.2 & 6.2 & 10.1 & 62 \\
\hline Yentna River near Susitna Station, Alaska & -4.3 & -8.1 & -6.4 & -7.5 & -10.9 & -6.8 & -9.8 & 1.9 & 5.5 & -6.6 & -12.2 & 1.2 & 91 \\
\hline Susitna River at Susitna Station, A laska & -9.0 & -9.9 & -4.7 & -6.8 & -8.5 & -8.8 & -10.2 & 1.9 & 1.3 & -6.7 & -3.6 & -2.2 & 70 \\
\hline
\end{tabular}


Table 7. Annual mean discharge for composite (observed and extended) records for selected streamgages in the Susitna River Basin, Alaska, water years 1950-2010.

[Streamgage locations and map identifiers are shown in figure 1]

\begin{tabular}{|c|c|c|c|c|c|c|c|c|c|c|c|}
\hline \multirow{2}{*}{$\begin{array}{l}\text { Water } \\
\text { year }\end{array}$} & \multicolumn{11}{|c|}{ Observed and extended annual mean discharge (cubic feet per second) } \\
\hline & SuDen & Mac & SuCant & SuGold & Chul & Talk & SuSun & Will & Skw & Yent & SuSta \\
\hline 1950 & 2,198 & 816 & 5,078 & 8,032 & 7,412 & 3,393 & 19,600 & 277 & 5,516 & 16,340 & 42,430 \\
\hline 1951 & 2,620 & 978 & 5,785 & 9,106 & 8,467 & 3,863 & 22,340 & 394 & 6,187 & 18,520 & 47,340 \\
\hline 1952 & 2,572 & 962 & 6,060 & 9,529 & 8,189 & 4,033 & 22,950 & 423 & 6,279 & 18,330 & 46,820 \\
\hline 1953 & 2,831 & 1,066 & 6,412 & 10,090 & 9,238 & 4,260 & 24,690 & 351 & 6,829 & 20,430 & 52,150 \\
\hline 1954 & 2,812 & 1,037 & 6,146 & 9,681 & 8,894 & 4,087 & 23,740 & 308 & 6,557 & 19,570 & 49,750 \\
\hline 1955 & 2,727 & 1,033 & 6,516 & 10,260 & 8,730 & 4,321 & 24,610 & 391 & 6,727 & 19,700 & 50,300 \\
\hline 1956 & 3,179 & 1,192 & 7,315 & 11,450 & 9,790 & 4,876 & 27,600 & 343 & 7,424 & 21,790 & 55,220 \\
\hline 1957 & 3,646 & 1,103 & 6,606 & 10,380 & 9,241 & 4,363 & 25,270 & 361 & 6,951 & 20,640 & 52,270 \\
\hline 1958 & 2,514 & 1,106 & 5,995 & 9,476 & 8,765 & 3,969 & 22,990 & 271 & 6,420 & 18,880 & 48,680 \\
\hline 1959 & 2,614 & 843 & 6,707 & 10,560 & 8,376 & 4,068 & 25,480 & 405 & 6,915 & 20,410 & 51,720 \\
\hline 1960 & 2,896 & 1,184 & 6,145 & 9,690 & 8,363 & 3,917 & 23,570 & 340 & 6,387 & 17,910 & 47,690 \\
\hline 1961 & 2,655 & 1,111 & 6,463 & 10,810 & 9,451 & 4,352 & 26,300 & 382 & 7,255 & 20,320 & 52,230 \\
\hline 1962 & 3,191 & 1,011 & 7,995 & 11,570 & 8,818 & 4,365 & 27,540 & 431 & 5,699 & 15,990 & 47,930 \\
\hline 1963 & 3,148 & 1,287 & 7,372 & 11,070 & 8,268 & 4,151 & 26,680 & 500 & 5,854 & 16,410 & 47,100 \\
\hline 1964 & 2,604 & 960 & 6,615 & 9,774 & 9,312 & 3,952 & 22,590 & 352 & 6,266 & 17,540 & 42,660 \\
\hline 1965 & 2,510 & 985 & 6,629 & 10,170 & 9,365 & 4,749 & 25,790 & 385 & 6,628 & 18,560 & 49,260 \\
\hline 1966 & 2,411 & 816 & 5,190 & 9,432 & 8,648 & 4,221 & 23,630 & 327 & 6,427 & 18,010 & 46,260 \\
\hline 1967 & 2,970 & 1,149 & 6,843 & 11,220 & 11,110 & 4,470 & 26,860 & 423 & 5,607 & 15,720 & 45,200 \\
\hline 1968 & 3,430 & 896 & 6,131 & 9,789 & 9,172 & 4,468 & 24,560 & 379 & 6,438 & 18,030 & 46,830 \\
\hline 1969 & 2,290 & 697 & 4,186 & 5,597 & 6,110 & 2,249 & 13,950 & 205 & 5,199 & 14,580 & 33,450 \\
\hline 1970 & 2,243 & 735 & 4,548 & 7,591 & 8,736 & 3,500 & 19,690 & 308 & 7,241 & 20,260 & 46,630 \\
\hline 1971 & 2,903 & 1,092 & 6,824 & 10,250 & 8,406 & 5,299 & 25,400 & 399 & 6,937 & 19,390 & 47,830 \\
\hline 1972 & 2,937 & 1,059 & 6,907 & 10,860 & 8,340 & 4,479 & 26,460 & 402 & 5,998 & 16,810 & 46,730 \\
\hline 1973 & 2,242 & 890 & 5,107 & 8,087 & 7,589 & 3,851 & 20,850 & 350 & 5,243 & 14,720 & 41,360 \\
\hline 1974 & 2,960 & 846 & 4,822 & 7,630 & 7,910 & 3,325 & 19,530 & 337 & 5,156 & 14,480 & 39,990 \\
\hline 1975 & 3,003 & 1,033 & 6,549 & 10,280 & 8,969 & 4,336 & 25,390 & 410 & 6,491 & 18,920 & 46,100 \\
\hline 1976 & 2,578 & 920 & 5,166 & 8,169 & 7,589 & 3,398 & 20,500 & 311 & 5,823 & 17,200 & 42,990 \\
\hline 1977 & 3,048 & 1,156 & 6,405 & 10,110 & 8,745 & 4,355 & 24,750 & 434 & 10,060 & 26,260 & 55,980 \\
\hline 1978 & 2,683 & 925 & 5,155 & 8,194 & 7,659 & 3,301 & 20,420 & 256 & 6,372 & 17,760 & 42,000 \\
\hline 1979 & 3,039 & 886 & 6,032 & 9,490 & 8,937 & 4,446 & 23,990 & 433 & 6,629 & 20,700 & 53,670 \\
\hline 1980 & 2,912 & 1,015 & 6,772 & 10,720 & 9,650 & 4,345 & 26,100 & 511 & 9,053 & 26,010 & 61,920 \\
\hline
\end{tabular}

\section{Accuracy and Limitations of Extended Record}

The accuracy of the estimates for daily discharge is indicated by two statistics, the root mean square error (RM SE) of the estimating equations for each index station, and the Nash Sutcliffe efficiency (NSE) statistics for the final values, which could include more than one index station. The regression equation model RM SE (table 3) indicates the fit of the multi-segment line to the plot of the logs of the concurrent daily values for every index station/site of interest pair. These model RMSEs ranged from 0.05 to 0.18 . The NSE statistic provided a measure of the fit of the final predicted values (the weighted value when more than one index station was used) to the observed record. NSE coefficients for the final models ranged from 0.75 to 0.93 (table 9 ). B oth of these statistics measure the strength of the fit during the concurrent period, but cannot evaluate the error in the values for the extended period. 
Table 7. Annual mean discharge for composite (observed and extended) records for selected streamgages in the Susitna River Basin, Alaska, water years 1950-2010.-Continued

[Streamgage locations and map identifiers are shown in figure 1]

\begin{tabular}{|c|c|c|c|c|c|c|c|c|c|c|c|}
\hline \multirow{2}{*}{$\begin{array}{c}\text { Water } \\
\text { year }\end{array}$} & \multicolumn{11}{|c|}{ Observed and extended annual mean discharge (cubic feet per second) } \\
\hline & SuDen & Mac & SuCant & SuGold & Chul & Talk & SuSun & Will & Skw & Yent & SuSta \\
\hline 1981 & 3,395 & 1,168 & 7,887 & 11,960 & 10,410 & 4,416 & 28,350 & 367 & 9,055 & 24,920 & 55,730 \\
\hline 1982 & 2,622 & 806 & 6,019 & 9,668 & 8,455 & 4,204 & 24,080 & 427 & 6,132 & 18,640 & 47,080 \\
\hline 1983 & 2,827 & 994 & 6,515 & 9,924 & 8,224 & 3,635 & 23,570 & 349 & 6,390 & 18,330 & 43,830 \\
\hline 1984 & 2,927 & 938 & 6,648 & 9,578 & 8,457 & 3,635 & 23,490 & 331 & 6,952 & 19,970 & 45,370 \\
\hline 1985 & 3,003 & 1,072 & 5,933 & 9,880 & 8,456 & 4,259 & 24,300 & 468 & 6,844 & 19,670 & 47,260 \\
\hline 1986 & 2,969 & 1,062 & 5,773 & 8,531 & 7,472 & 3,352 & 20,620 & 320 & 6,481 & 19,680 & 46,350 \\
\hline 1987 & 3,060 & 1,072 & 6,706 & 10,550 & 9,865 & 4,812 & 26,740 & 416 & 7,755 & 23,600 & 54,900 \\
\hline 1988 & 3,046 & 983 & 6,501 & 10,220 & 8,077 & 3,736 & 24,840 & 349 & 7,521 & 22,850 & 53,570 \\
\hline 1989 & 3,210 & 1,033 & 6,503 & 10,250 & 8,957 & 4,239 & 25,550 & 413 & 7,985 & 24,410 & 56,480 \\
\hline 1990 & 3,698 & 1,286 & 8,308 & 13,020 & 10,940 & 5,389 & 31,770 & 536 & 8,609 & 26,380 & 61,190 \\
\hline 1991 & 2,603 & 855 & 5,391 & 8,532 & 7,940 & 3,779 & 21,610 & 383 & 6,743 & 20,590 & 48,200 \\
\hline 1992 & 2,425 & 863 & 5,514 & 8,720 & 7,512 & 3,525 & 21,590 & 335 & 6,081 & 18,370 & 43,900 \\
\hline 1993 & 3,043 & 1,093 & 6,411 & 10,100 & 10,010 & 4,839 & 26,020 & 383 & 6,834 & 20,400 & 53,120 \\
\hline 1994 & 2,772 & 990 & 6,302 & 9,960 & 9,169 & 4,344 & 25,070 & 413 & 6,709 & 19,810 & 51,770 \\
\hline 1995 & 2,847 & 1,020 & 6,537 & 10,290 & 8,682 & 4,039 & 25,420 & 360 & 6,975 & 20,610 & 51,330 \\
\hline 1996 & 1,855 & 648 & 4,260 & 6,800 & 6,789 & 3,115 & 17,700 & 245 & 4,750 & 13,810 & 38,290 \\
\hline 1997 & 2,435 & 827 & 5,514 & 8,800 & 7,667 & 3,581 & 23,140 & 317 & 6,049 & 18,440 & 44,550 \\
\hline 1998 & 2,666 & 907 & 5,886 & 9,382 & 8,233 & 3,854 & 24,550 & 336 & 6,379 & 19,480 & 47,080 \\
\hline 1999 & 2,519 & 864 & 5,808 & 9,294 & 8,078 & 3,850 & 24,370 & 326 & 6,361 & 19,510 & 46,590 \\
\hline 2000 & 2,745 & 963 & 6,397 & 10,230 & 8,900 & 4,447 & 26,620 & 429 & 6,913 & 21,100 & 50,260 \\
\hline 2001 & 2,506 & 901 & 6,026 & 9,539 & 7,845 & 3,703 & 23,790 & 355 & 6,379 & 19,170 & 46,930 \\
\hline 2002 & 2,421 & 865 & 5,364 & 8,483 & 8,095 & 3,801 & 21,680 & 315 & 5,800 & 17,110 & 45,130 \\
\hline 2003 & 2,819 & 1,002 & 6,514 & 10,280 & 9,083 & 4,248 & 25,630 & 338 & 6,927 & 20,330 & 52,430 \\
\hline 2004 & 2,574 & 912 & 5,955 & 9,396 & 7,899 & 3,606 & 23,320 & 268 & 6,401 & 18,920 & 47,740 \\
\hline 2005 & 3,656 & 1,330 & 7,821 & 12,210 & 11,700 & 5,856 & 30,880 & 607 & 7,973 & 23,600 & 61,390 \\
\hline 2006 & 2,706 & 983 & 6,552 & 10,310 & 8,285 & 4,014 & 24,940 & 434 & 6,800 & 20,040 & 49,470 \\
\hline 2007 & 2,548 & 917 & 6,102 & 9,649 & 7,838 & 3,588 & 23,750 & 313 & 6,636 & 19,780 & 48,520 \\
\hline 2008 & 2,357 & 844 & 5,626 & 8,905 & 7,458 & 3,424 & 22,010 & 314 & 6,115 & 18,040 & 45,280 \\
\hline 2009 & 2,525 & 904 & 6,022 & 9,499 & 7,731 & 3,558 & 23,390 & 289 & 6,472 & 19,210 & 47,690 \\
\hline 2010 & 2,724 & 983 & 6,442 & 10,140 & 8,178 & 3,765 & 24,850 & 293 & 6,870 & 20,500 & 50,300 \\
\hline
\end{tabular}

In addition to the accuracy of the estimates, users should consider limitations inherent in the data or introduced by the streamflow extension methods. The quality of the flow records for periods of estimated streamflow (including ice-affected winter periods, and periods of likely estimated data in 1954, 1956, 1958, and 1961-63 at Susitna River at Gold Creek) are categorized by the USGS as poor, indicating that the values may diverge from the actual values by more than 8 percent.

The effect of establishing multi-segment regression lines on the basis of magnitude of streamflow, rather than by seasons, is that annual estimates will be more accurate than monthly or daily estimates. For example, for Susitna River near Denali, the index stations generally slightly overestimated early-season peaks (similar to the case in fig. 6B) and slightly underestimated mid-summer peaks. The extended records are less appropriate for analyzing specifics of the distribution of flows across a season (such as the date of occurrence of the highest flows within the high flow season) than for computing statistics that synthesize streamflow over a month or longer.

Predicted low flows generally did not match observed low flows as well as predicted high flows matched observed high flows. Under-ice low flow is estimated, and can be driven by hydrologic basin conditions not shared by other basins. Conclusions about patterns in low flows should consider the greater uncertainty in these values. 
Table 8. Mean annual discharge for composite (observed and extended) records and difference from observed records for selected streamgages in the Susitna River Basin, Alaska, water years 1950-2010.

[Streamgage locations and map identifiers are shown in figure 1. Difference in mean annual discharge between composite and observed records: Positive values indicate that the values in the composite record are greater than the values in the observed record only. A bbreviations: $\mathrm{ft}^{3} / \mathrm{s}$, cubic feet per second; WY, water year]

\begin{tabular}{lcc}
\hline \multicolumn{1}{c}{ Streamgage name } & $\begin{array}{c}\text { Mean annual } \\
\text { discharge for } \\
\text { composite record, } \\
\text { WY 1950-2010 } \\
\text { (ft/s) }\end{array}$ & $\begin{array}{c}\text { Difference in mean annual } \\
\text { discharge between } \\
\text { composite record } \\
\text { (WY 1950-2010) and } \\
\text { observed record (period } \\
\text { varies) (percent) }\end{array}$ \\
\hline Susitna River near Denali, A laska & 2,785 & 0.4 \\
Maclaren River near Paxson, Alaska & 982 & 0.1 \\
Susitna River near Cantwell, Alaska & 6,192 & -3.1 \\
Susitna River at Gold Creek, A laska & 9,724 & -0.2 \\
Chulitna River near Talkeetna, A laska & 8,601 & -1.8 \\
Talkeetna River near Talkeetna, A laska & 4,055 & 0.6 \\
Susitna River at Sunshine, A laska & 24,060 & 0.8 \\
Willow Creek near Willow, Alaska & 368 & -3.9 \\
Skwentna River near Skwentna, Alaska & 6,663 & 0.8 \\
Yentna River near Susitna Station, Alaska & 19,470 & -4.1 \\
Susitna River at Susitna Station, Alaska & 48,560 & -3.6 \\
\hline
\end{tabular}

Table 9. Nash Sutcliffe efficiency (NSE) coefficients comparing observed and predicted discharge values at selected streamgages in the Susitna River Basin, Alaska.

[Streamgage locations and map identifiers are shown in figure 1. NSE, modified Nash Sutcliffe efficiency coefficient (Legates and M cCabe, 1999)]

\begin{tabular}{llll}
\hline \multicolumn{1}{c}{ Streamgage name } & $\begin{array}{c}\text { USGS station } \\
\text { identification } \\
\text { No. }\end{array}$ & $\begin{array}{l}\text { Index stations used for } \\
\text { predicted values }\end{array}$ & $\begin{array}{c}\text { NSE for full } \\
\text { period of } \\
\text { observed values }\end{array}$ \\
\hline Susitna River near D enali, A laska & 15291000 & SuG old, Talk, SuSta & 0.78 \\
Maclaren River near Paxson, Alaska & 15291200 & SuG old, Talk & 0.80 \\
Susitna River near Cantwell, Alaska & 15291500 & SuG old, Talk & 0.86 \\
Susitna River at Gold Creek, A laska & 15292000 & Talk & 0.81 \\
Chulitna River near Talkeetna, A laska & 15292400 & SuG old, Talk, SuDen & 0.85 \\
Talkeetna River near Talkeetna, A laska & 15292700 & SuG old, Chul & 0.82 \\
Susitna River at Sunshine, Alaska & 15292780 & SuG old, Talk & 0.93 \\
Willow Creek near Willow, Alaska & 15294005 & LSu & 0.75 \\
Skwentna River near Skwentna, Alaska & 15294300 & SuGold, Yent, SuSta, Talk & 0.78 \\
Yentna River near Susitna Station, Alaska & 15294345 & SuGold, Skw, SuSta, Talk & 0.88 \\
Susitna River at Susitna Station, A laska & 15294350 & SuGold, Skw, Talk & 0.86 \\
\hline
\end{tabular}




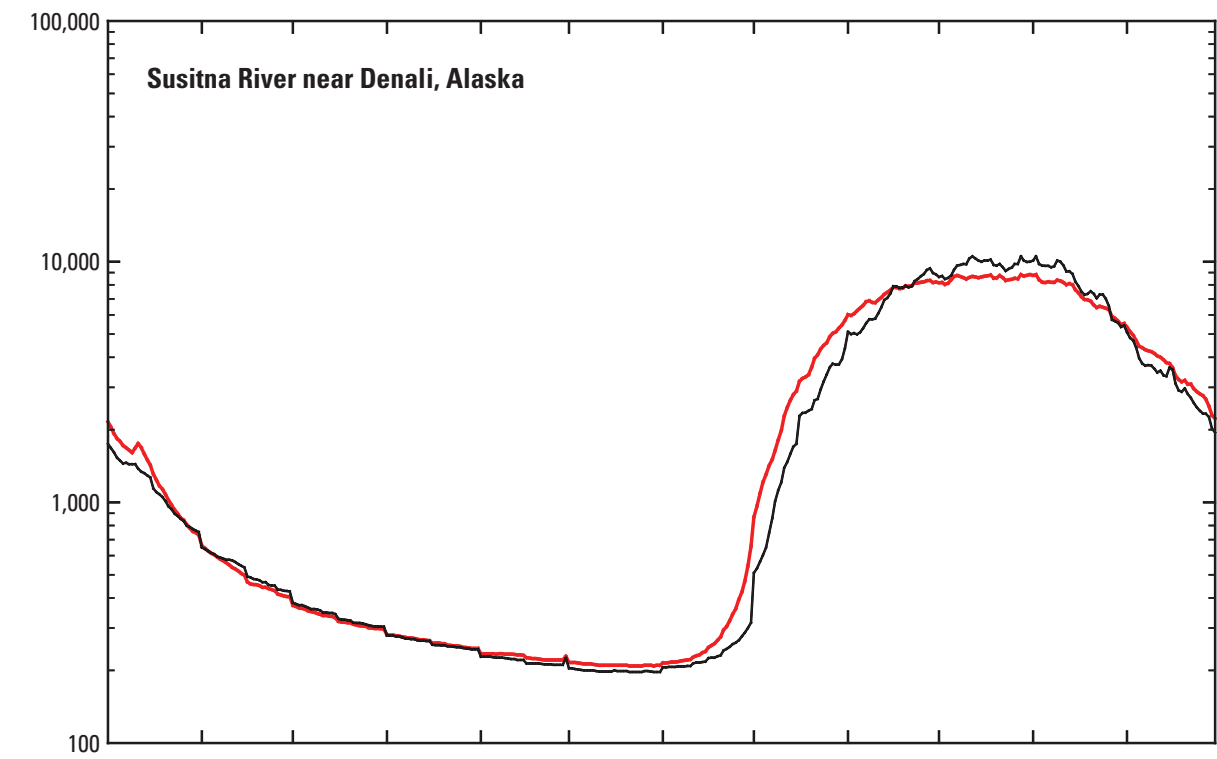

EXPLANATION
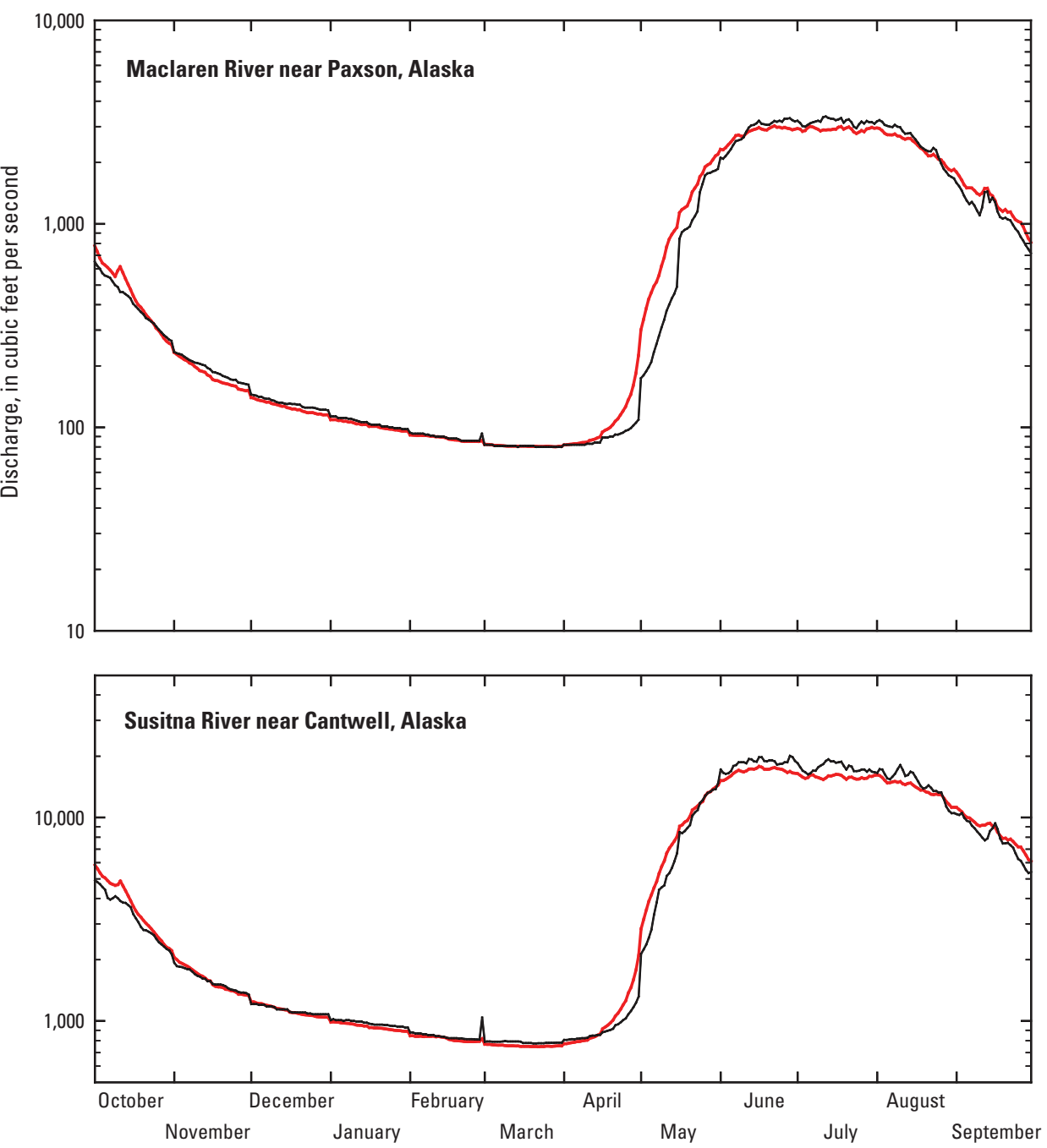

Figure 8. Mean daily discharge for composite (observed and extended) records for water year 1950-2010 and observed records for the available period of record for selected streamgages, Susitna River Basin, Alaska. Plots show the mean of all discharge values for each calendar day during the respective period of record. Locations, full station names, numbers, and map identifiers are shown in figure 1. 


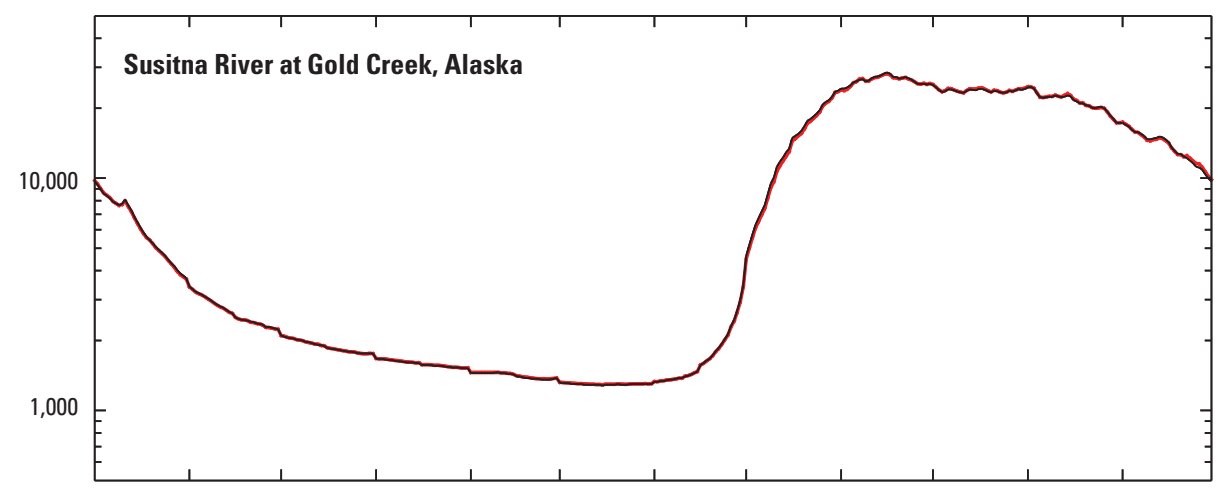

EXPLANATION

Observed and extended record Observed record
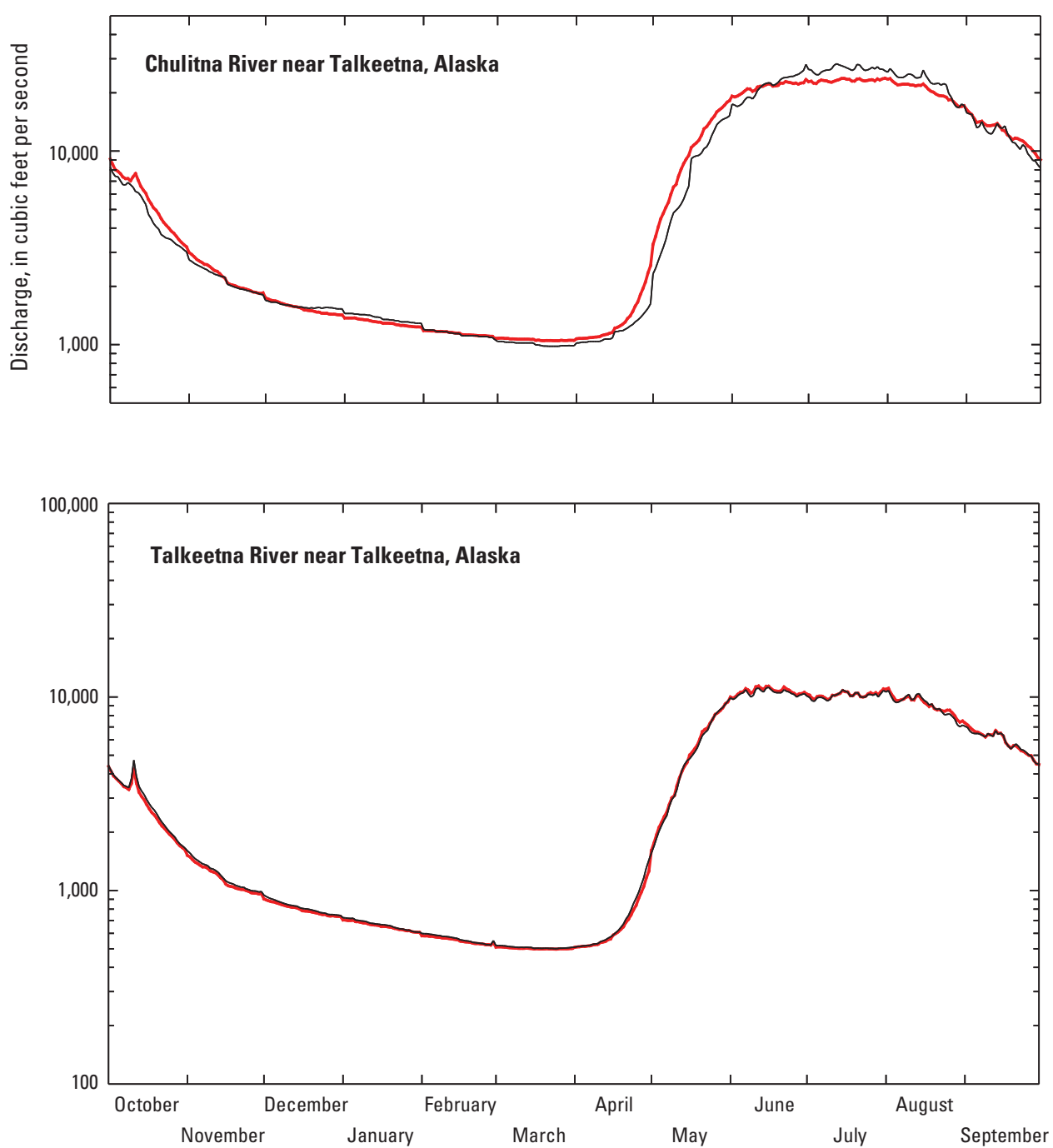

Figure 8.-Continued 


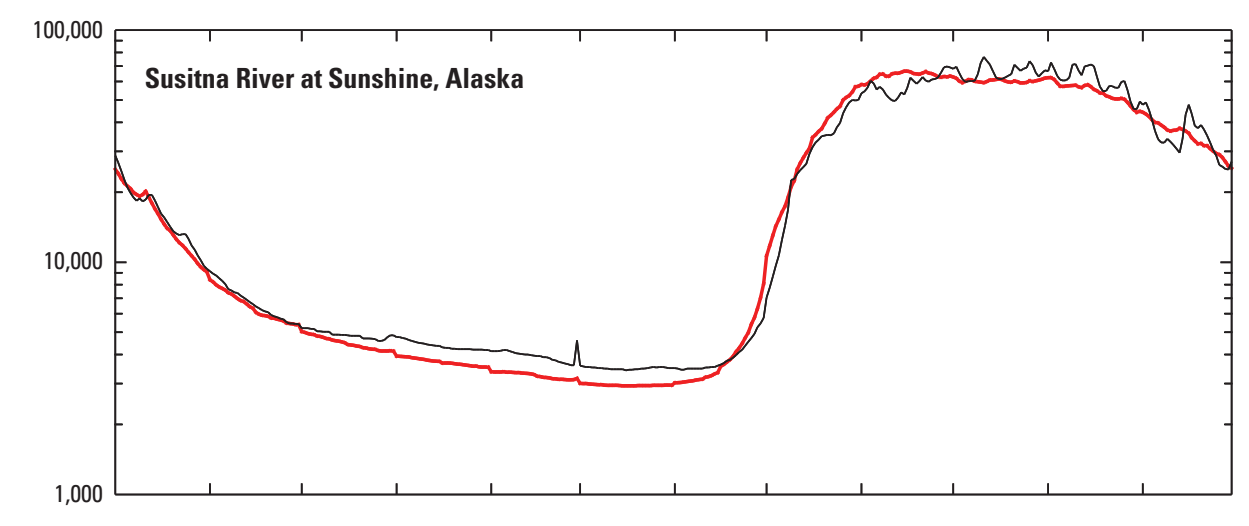

\section{EXPLANATION}
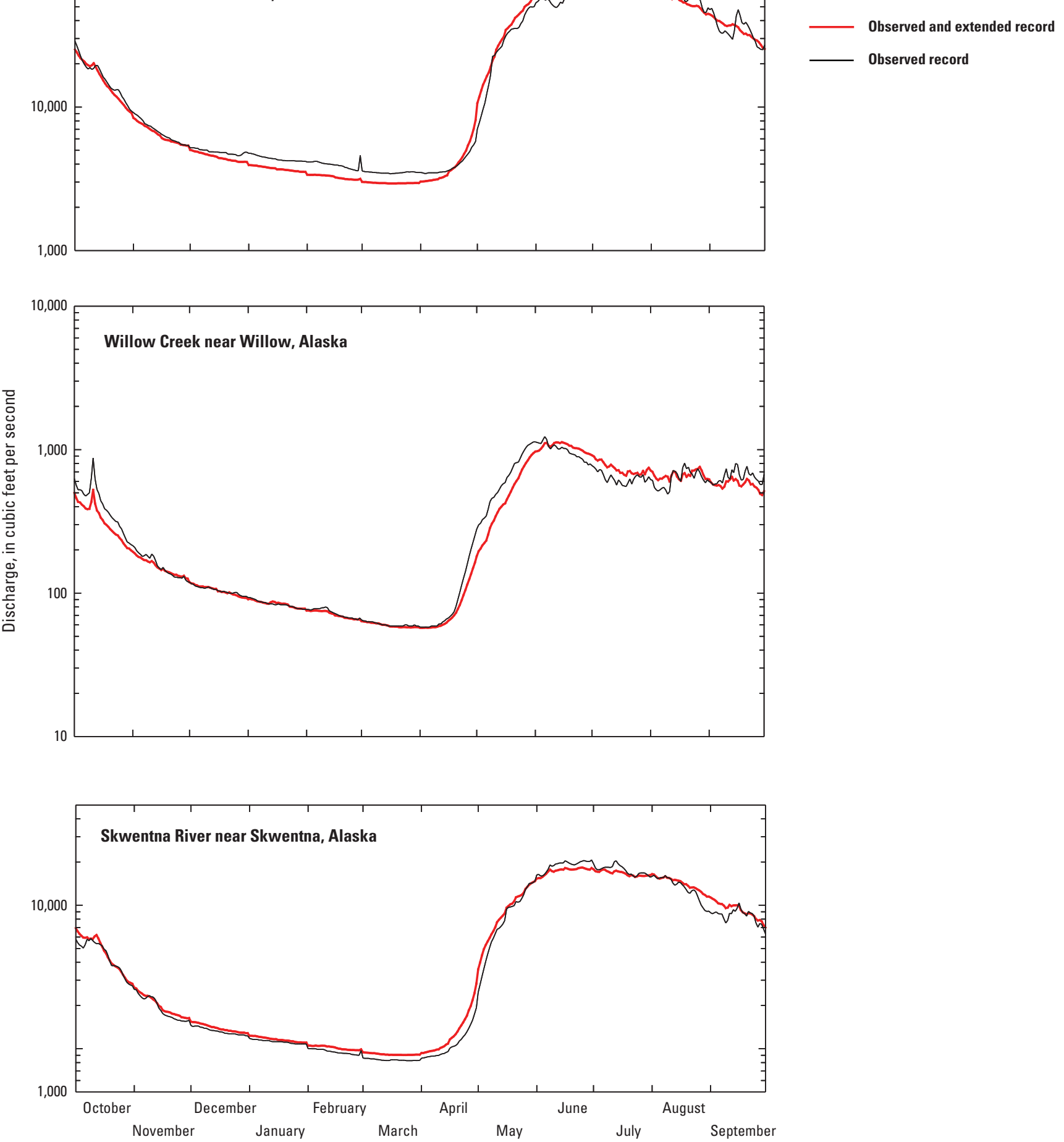

Figure 8.-Continued 
Streamflow Record Extension for Selected Streams in the Susitna River Basin, Alaska

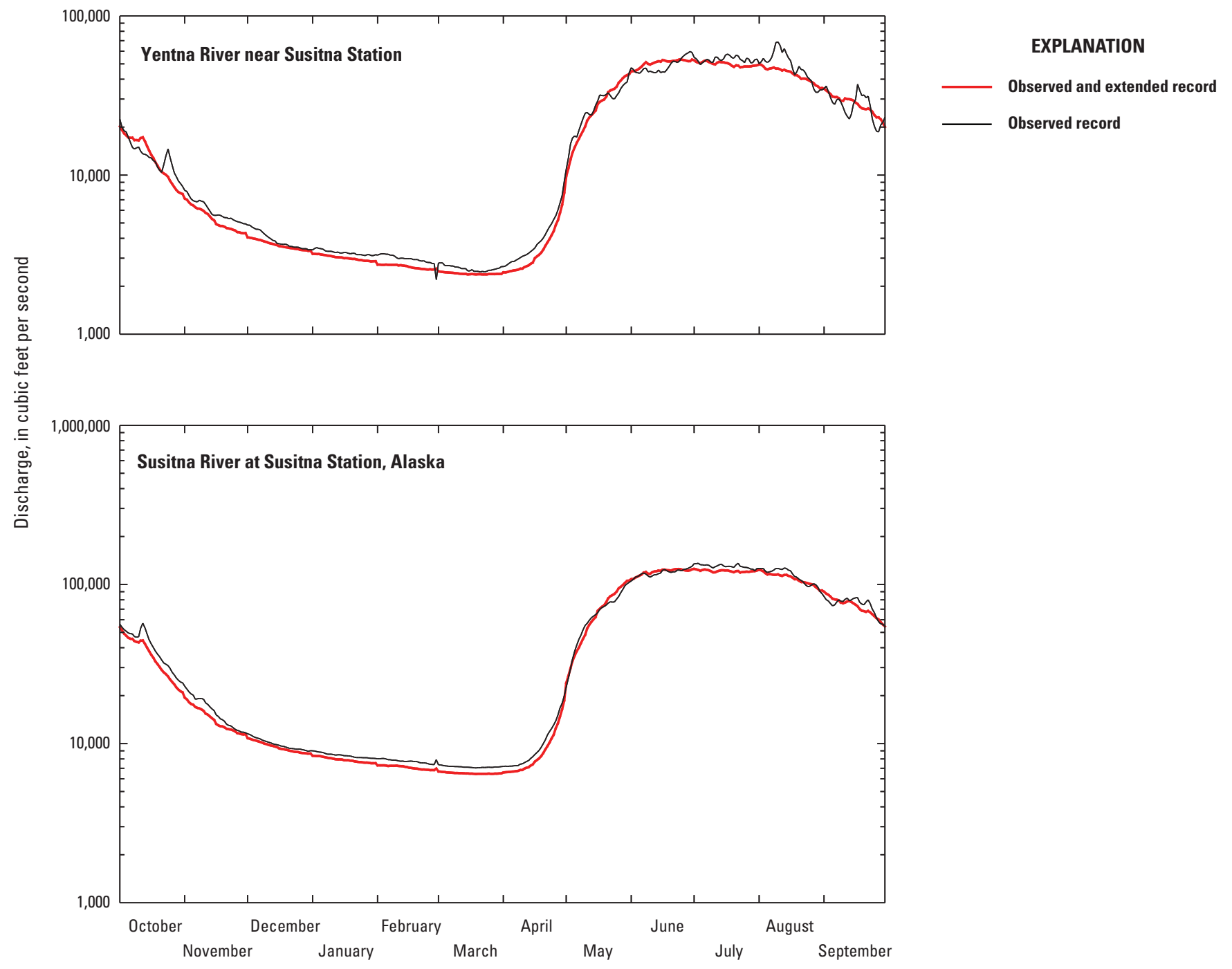

Figure 8.-Continued 


\section{Summary}

Streamflow data in the Susitna River Basin include records from 14 streamgages during the period of water year 1950-2010, but no single streamgage collected data for the entire period. Additionally, many streamgages were operated for mostly one phase of the Pacific Decadal Oscillation (PDO), a climate pattern that affects streamflow timing, and thus may not represent long-term flow patterns. Streamflow records can be extended to estimate flow for a site of interest when daily discharge at an index station is well correlated with daily discharge at the site and available for the desired extended period. The extended streamflow records then provide a continuous string of daily discharge and can improve long-term streamflow statistics.

To examine the suitability of record extension for streams in the Susitna River Basin, the streams were sorted into glacier-melt, snowmelt-and-glacier-melt, snowmelt, and snowmelt-and-rainfall dominated groups on the basis of the relative magnitude of and trends in spring and summer streamflow. Correlation coefficients computed for all possible pairs of sites and index stations showed adequate correlation ( $r$ greater than 0.95 ) with one or more index stations for the study period for all but three lowland sites in the snowmeltand-rainfall dominated group, M ontana C reek, Deception Creek, and the Deshka River. Records for streams in which the flow showed at least a moderate mid-summer effect of glacier melt correlated better with the records for the long-term index stations, Susitna River at Gold Creek and Talkeetna River near Tal keetna, than did records for streams not affected by glacier melt.

The K endall-Theil Robust Line method, a nonparametric approach to regression analysis, provided the most technically appropriate and computationally feasible method for extending streamflow records for the 11 well-correlated records. Multiple line segments addressed the variation in the relationship between stations for particularly high and low flows. Index stations were used singly or in pairs to compute extended records, and weighted by their respective error to produce final extended daily discharge values.

R esulting composited extended and observed records, when compared to the observed records only, show shifts in streamflow timing and magnitude largely as expected from the relative proportion of years in the PDO cool and warm phases added to the record. Monthly means for the months when breakup occurs, typically A pril or M ay, and for the typical freeze-up months of September or October, were higher for sites whose extended records were supplemented with warm phase PDO years and lower for those supplemented with cool phase PDO years. Monthly means were correspondingly lower through mid-to-late-summer (July and August) at sites whose extended records gained additional warm phase PDO years and in June for sites whose extended records gained additional cool phase PDO years.

\section{References Cited}

Alaska Energy Authority, 2011, Pre-application document, Susitna-Watana Hydroelectric Project: Alaska Energy Authority, FERC Project No. 14241, v. 1.

Conover, W.J., 1980, Practical nonparametric statistics, 2nd ed.: New York, Wiley, 493 p.

Gibson, W., 2009a, Mean precipitation for Alaska 1971-2000: National Park Service, Alaska Regional Office GIS Team, Geospatial Dataset-2170508.

Gibson, W., 2009b, M ean average temperature for A laska 1971-2000: National Park Service, Alaska Regional Office GIS Team, Geospatial Dataset-2170516.

Granato, G.E., 2006, Kendall-Theil Robust Line (K TR Lineversion 1.0)-A visual basic program for calculating and graphing robust nonparametric estimates of linearregression coefficients between two continuous variables: U.S. Geological Survey Techniques and M ethods, book 4, chap. A 7, 31 p. (A Iso available at http://pubs.usgs.gov/ tm/2006/tm4a7/.)

Granato, G.E., 2009, Computer programs for obtaining and analyzing daily mean streamflow data from the U.S. Geological Survey National Water Information System web site: U.S. Geological Survey Open-File Report 2008-1362, 123 p., on CD-ROM , 5 app. (A Iso available at http://pubs. usgs.gov/of/2008/1362/.) 
Hartmann, B., and Wendler, G., 2005, The significance of the 1976 Pacific climate shift in the climatology of Alaska: Journal of Climate, v. 18, no. 22, p. 4824-4839.

Helsel, D.R., and Hirsch, R.M ., 2002, Statistical methods in water resources: U.S. Geological Survey Techniques of Water Resources Investigations, book 4, chap. A 3, 522 p.

Hirsch, R.M., 1982, A comparison of four streamflow record extension techniques: Water Resources Research, v. 18, no. 4, p. 1081-1088.

Hodgkins, G.A., 2009, Streamflow changes in Alaska between the cool phase (1947-1976) and the warm phase (1977-2006) of the Pacific Decadal Oscillation-The influence of glaciers: Water Resources Research, v. 45, no. 6, p. W 06502.

Kammerer, J.C., 1990 (rev.), Largest rivers in the United States: U.S. Geological Survey Open-File Report 87-242, $2 \mathrm{p}$.

Legates, D.R., and McCabe, G.J., Jr., 1999, Evaluating the use of "goodness-of-fit" measures in hydrologic and hydroclimatic model validation: Water Resources Research, v. 35 , no. 1, p. $233-241$.

Mantua, N.J., Hare, S.R., Zhang, Y., Wallace, J.M., and Francis, R.C., 1997, A Pacific interdecadal climate oscillation with impacts on salmon production: Bulletin of the A merican M eteorological Society, v. 78, no. 6, p. 1069-1079.
Neal, E.G., Todd W.M., and Coffeen, C., 2002, Linking the pacific decadal oscillation to seasonal stream discharge patterns in Southeast Alaska: Journal of Hydrology, v. 263, no. 1, p. 188-197.

Sen, P.K., 1968, Estimates of the regression coefficient based on Kendall's Tau: Journal of the American Statistical Association, v. 63, no. 324, p. 1379-1389.

Theil, H., 1950, A rank-invariant method of linear and polynomial regression analysis, Part 3: Proceedings of Koninklijke Nederlandse Akademie van Wetenschappen, v. 53, p. 386-392, 521-525, 1397-1412.

University of Washington Joint Institute for the Study of the Atmosphere and Ocean, 2012, PDO index: University of Washington database, accessed September 4, 2012, at http:// jisao.washington.edu/pdo/PDO.latest.

U.S. Geological Survey, 2012, USGS surface-water data for A laska: U.S. Geological Survey database, accessed September 4, 2012, at http://waterdata.usgs.gov/ak/nwis/sw.

Vogel, R.M., and Stedinger, J.R., 1985, Minimum variance streamflow record augmentation procedures: Water Resources Research, v. 21, no. 5, p. 715-723. 


\section{Appendix A. Plots of Daily Discharge and Best-Fit Multi-Segment Kendall- Theil Regression Lines for Sites of Interest and Index Stations for Concurrent Periods during Water Years 1950-2010, Susitna River Basin, Alaska}
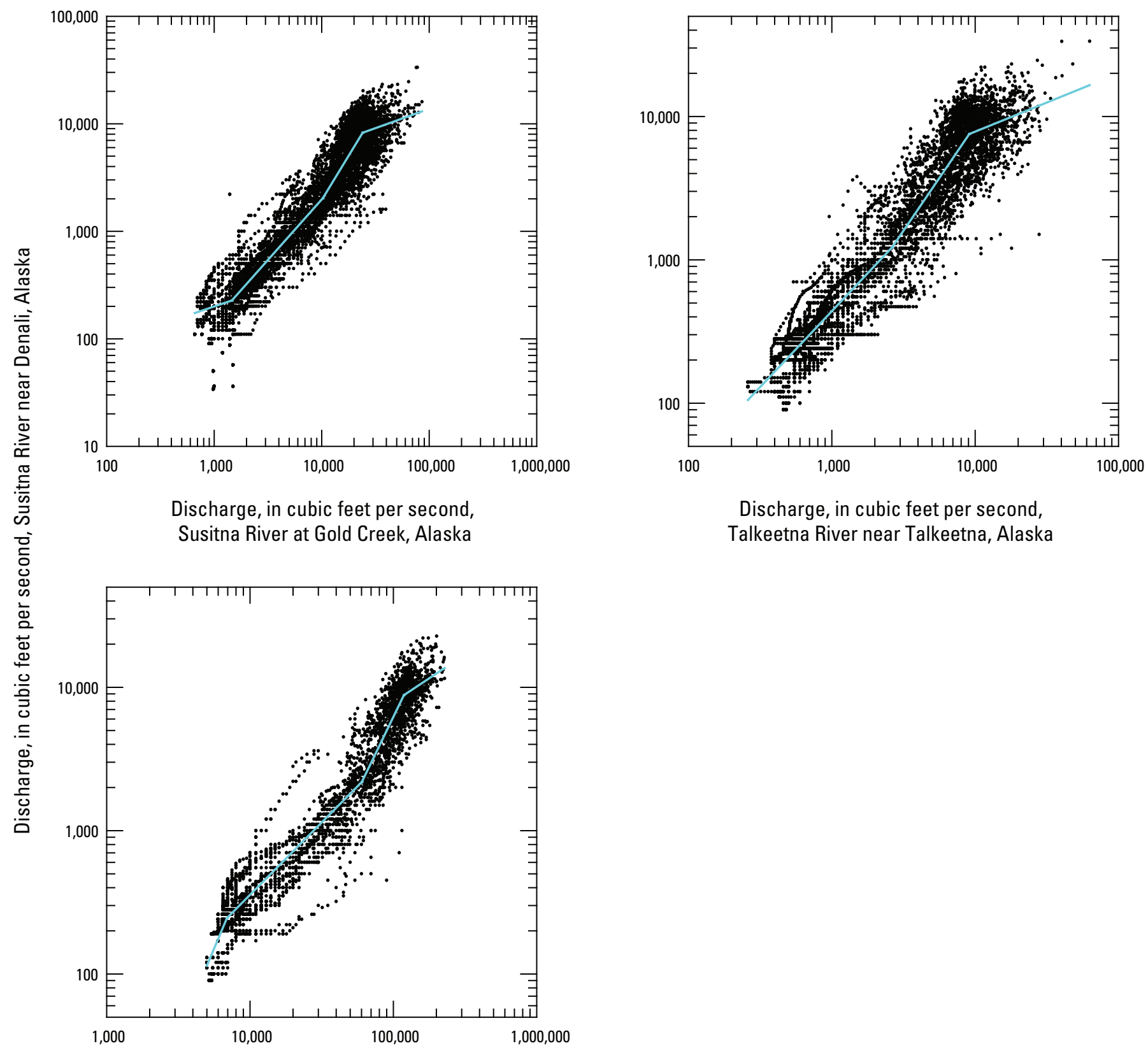

Discharge, in cubic feet per second,

Susitna River at Susitna Station, Alaska

Figure A1. Correlation of concurrent daily mean discharge between Susitna River near Denali and Susitna River at Gold Creek, Talkeetna River near Talkeetna, and Susitna River at Susitna Station, Susitna River Basin, Alaska, water years 1950-2010, and Kendall-Theil Robust Line regression line. 

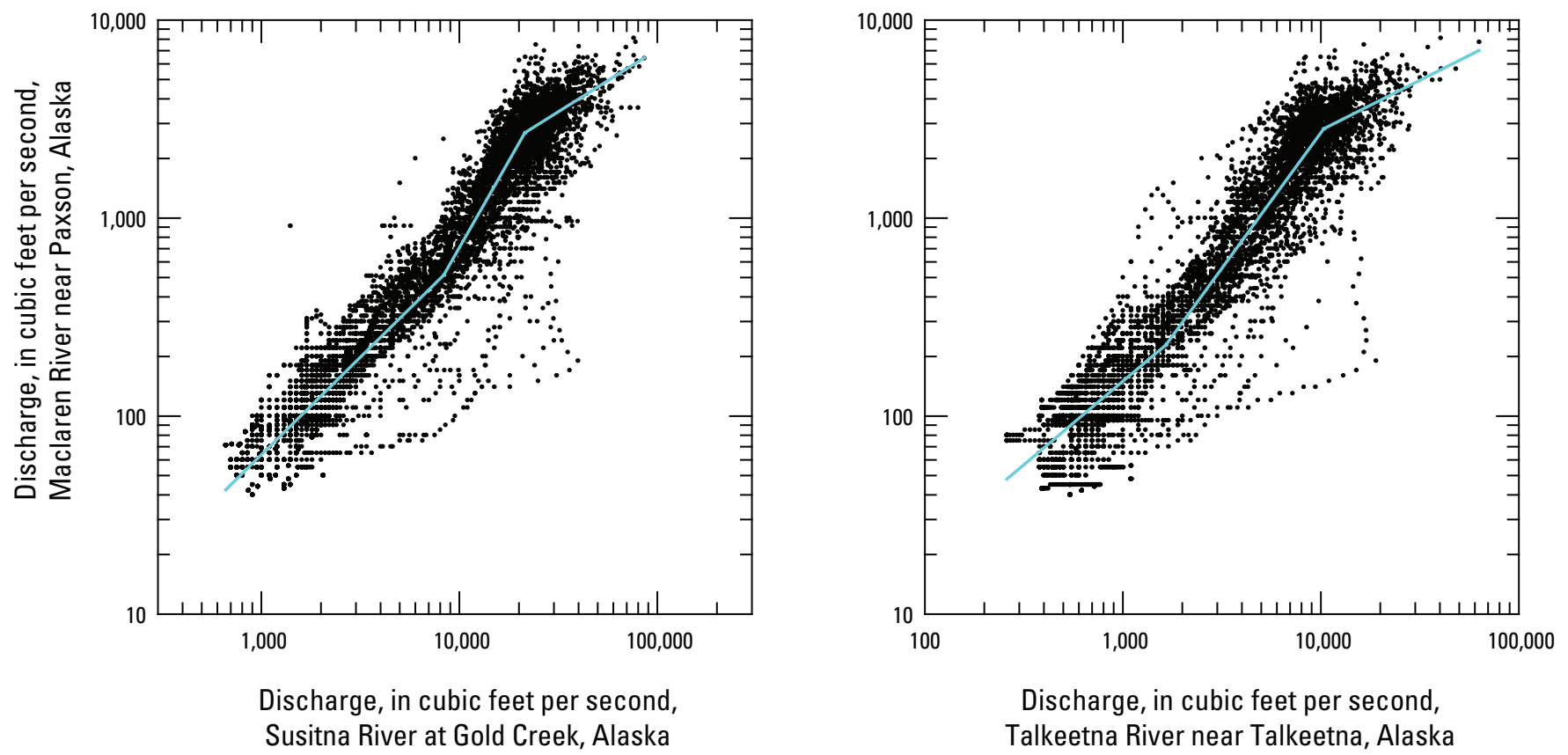

Figure A2. Correlation of concurrent daily mean discharge between Maclaren River near Paxson and Susitna River at Gold Creek and Talkeetna River near Talkeetna, Susitna River Basin, Alaska, water years 1950-2010, and Kendall-Theil Robust Line regression line.
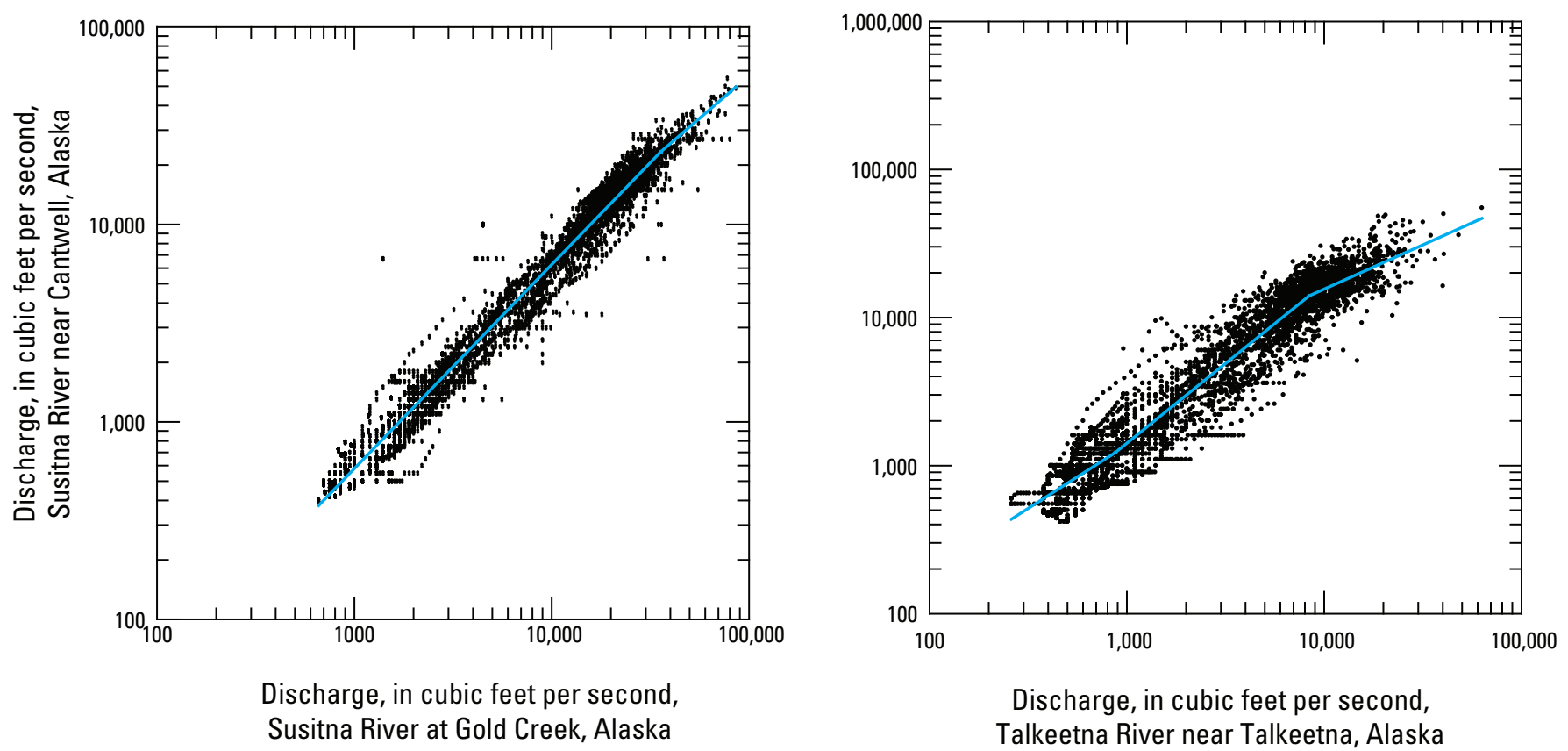

Discharge, in cubic feet per second, Talkeetna River near Talkeetna, Alaska

Figure A3. Correlation of concurrent daily mean discharge between Susitna River near Cantwell and Susitna River at Gold Creek and Talkeetna River near Talkeetna, Susitna River Basin, Alaska, water years 1950-2010, and Kendall-Theil Robust Line regression line. 

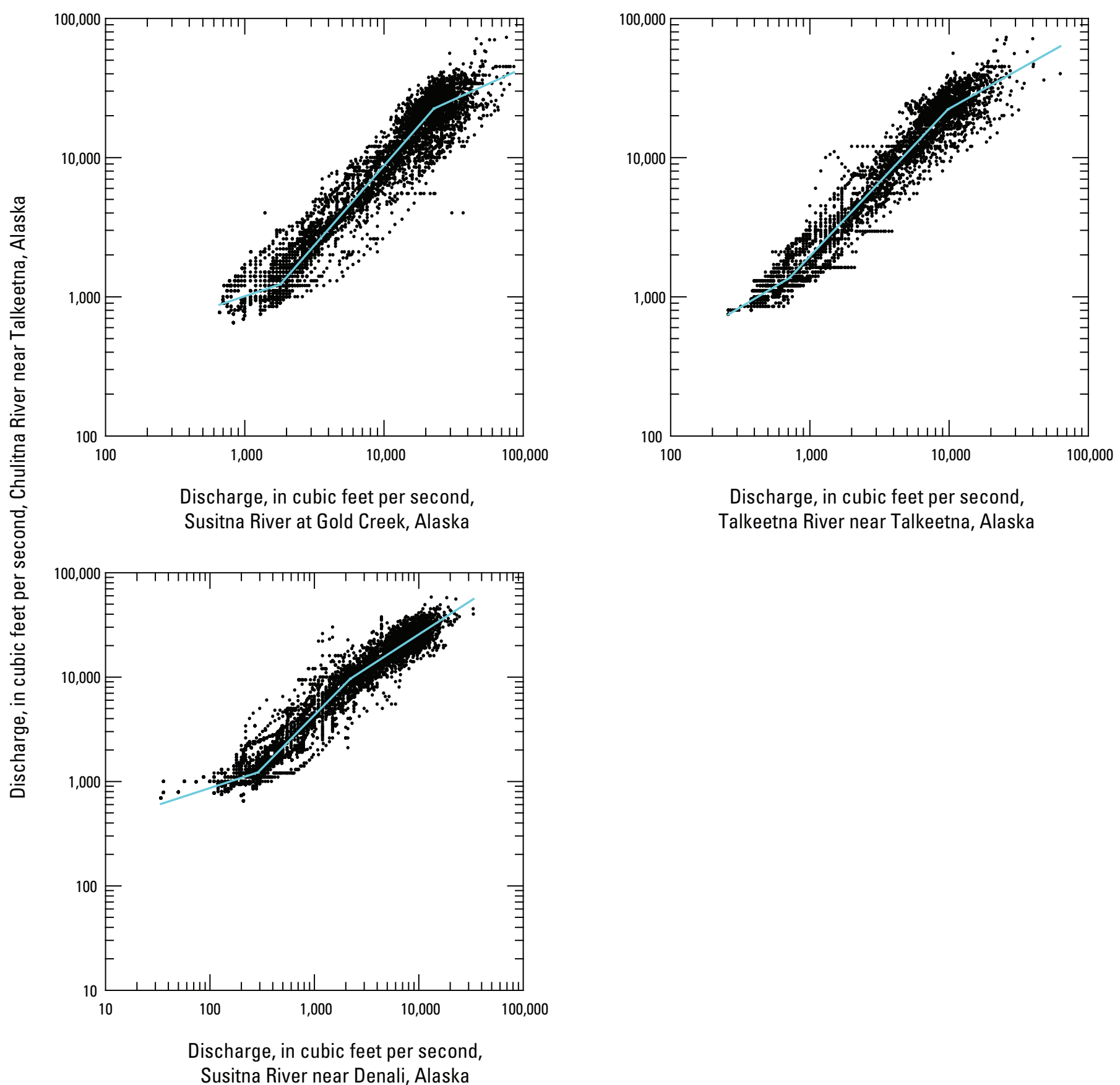

Figure A4. Correlation of concurrent daily mean discharge between Chulitna River near Talkeetna and Susitna River at Gold Creek, Talkeetna River near Talkeetna, and Susitna River near Denali, Susitna River Basin, Alaska, water years 1950-2010, and Kendall-Theil Robust Line regression line. 


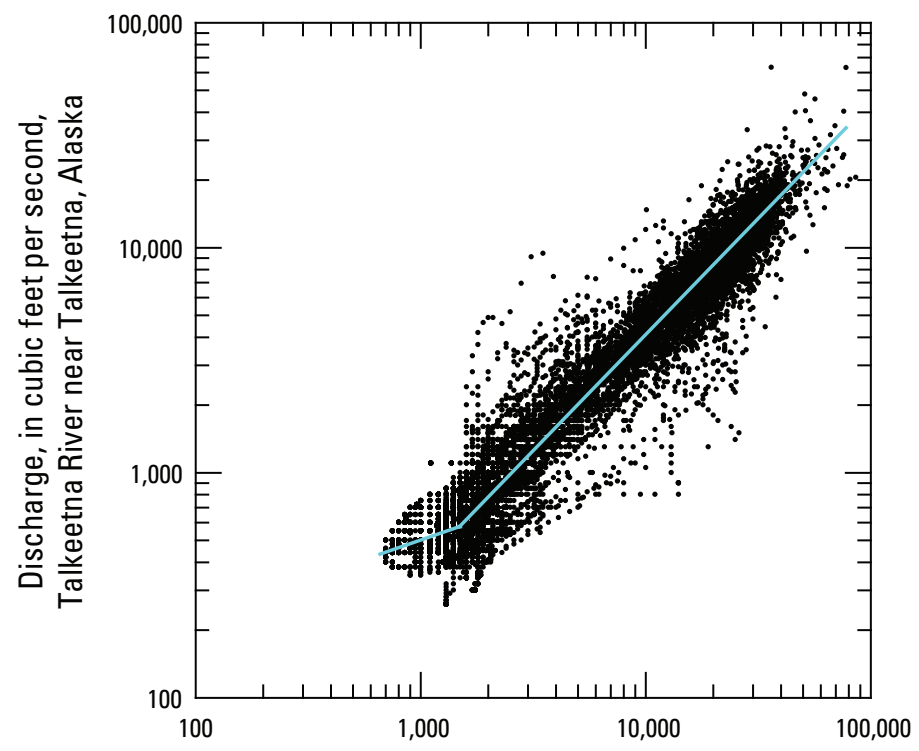

Discharge, in cubic feet per second,

Susitna River at Gold Creek, Alaska

Figure A5. Correlation of concurrent daily mean discharge between Talkeetna River near Talkeetna and Susitna River at Gold Creek, Susitna River Basin, Alaska, water years 1950-2010, and Kendall-Theil Robust Line regression line.
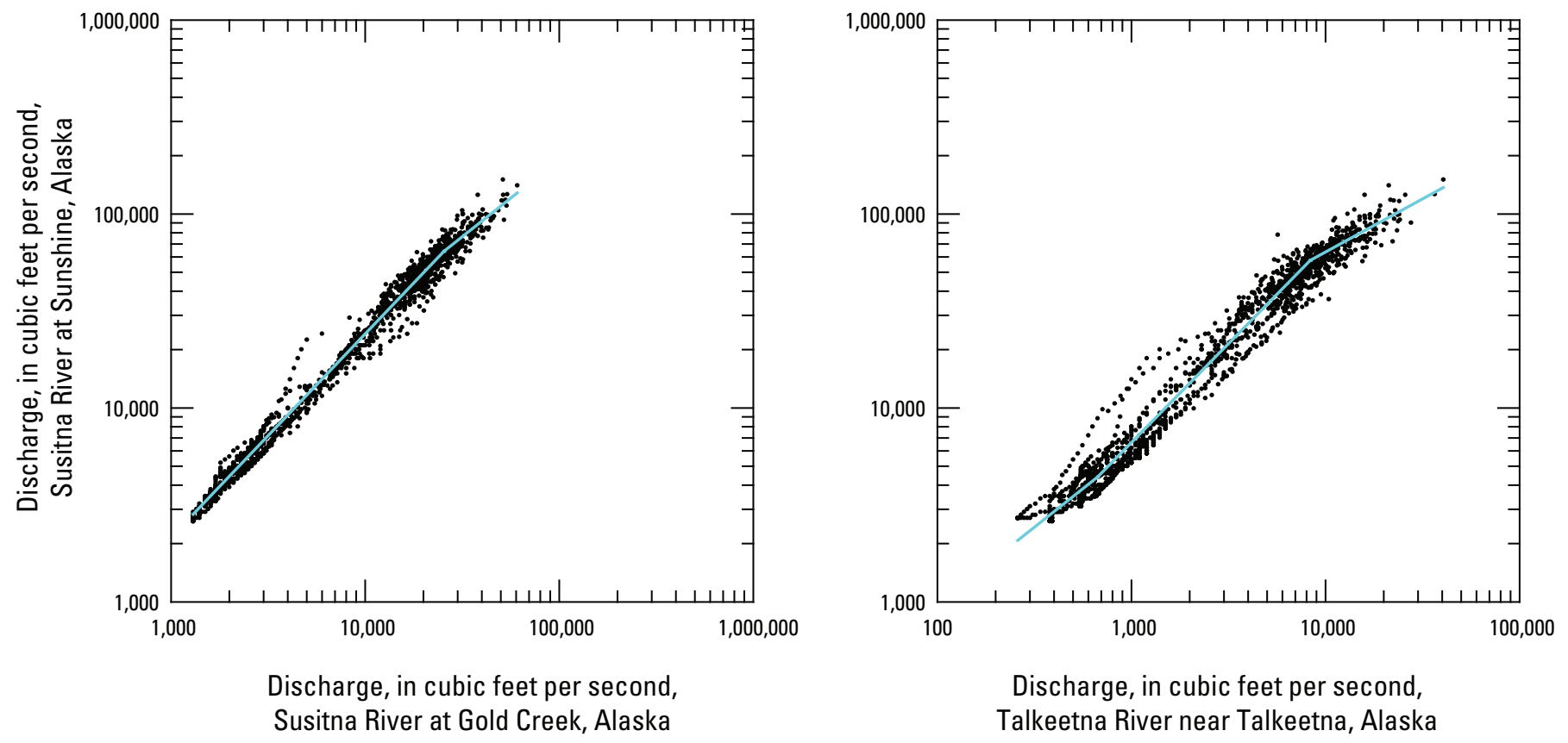

Figure A6. Correlation of concurrent daily mean discharge between Susitna River near Susitna and Susitna River at Gold Creek and Talkeetna River near Talkeetna, Susitna River Basin, Alaska, water years 1950-2010, and Kendall-Theil Robust Line regression line. 


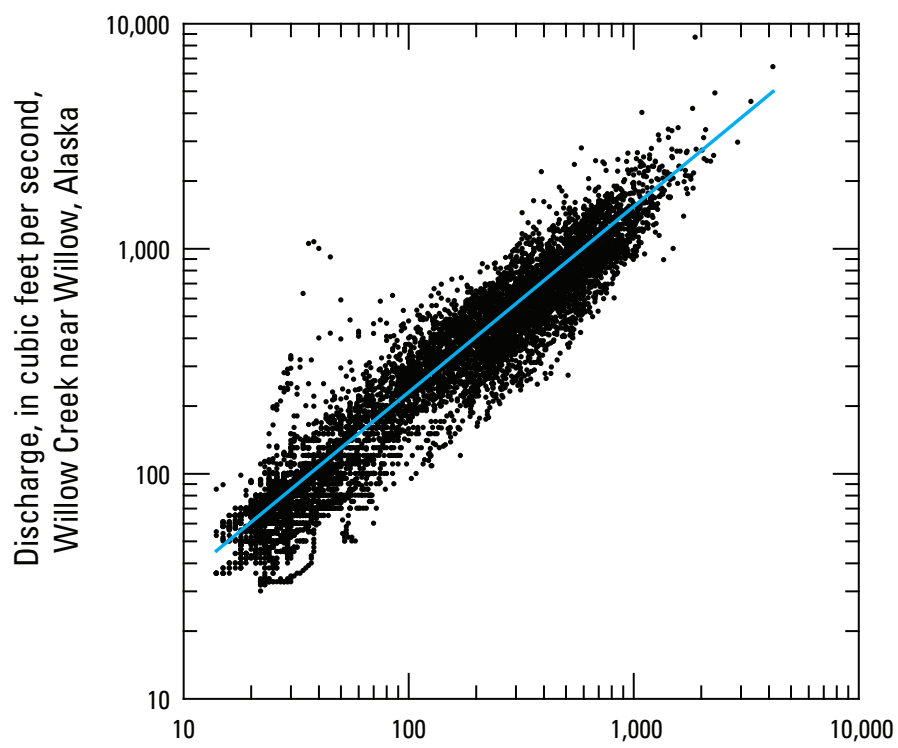

Discharge, in cubic feet per second, Little Susitna River near Palmer, Alaska

Figure A7. Correlation of concurrent daily mean discharge between Willow Creek near Willow and Little Susitna River near Palmer, Alaska, water years 1950-2010, and Kendall-Theil Robust Line regression line. 

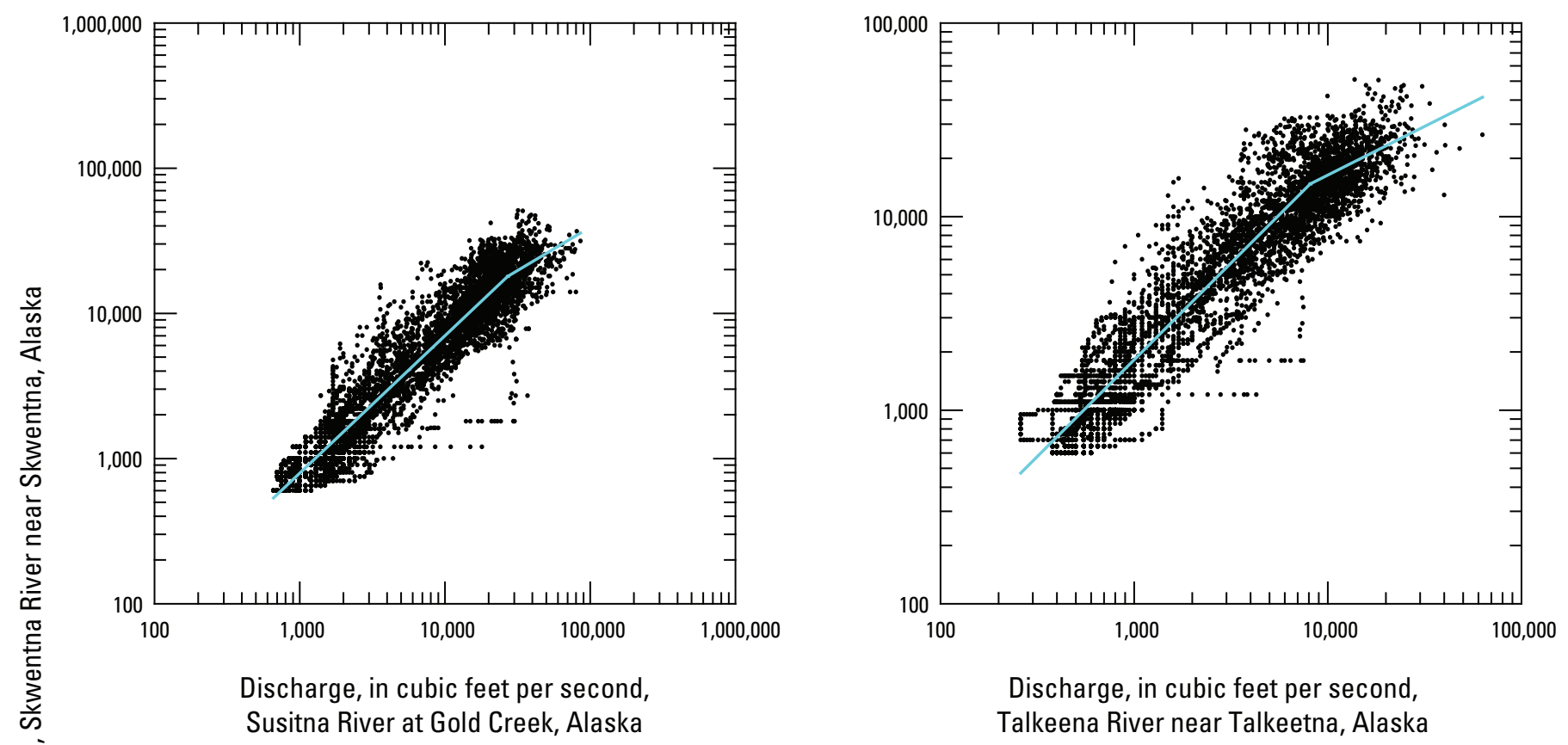

Discharge, in cubic feet per second,

Talkeena River near Talkeetna, Alaska

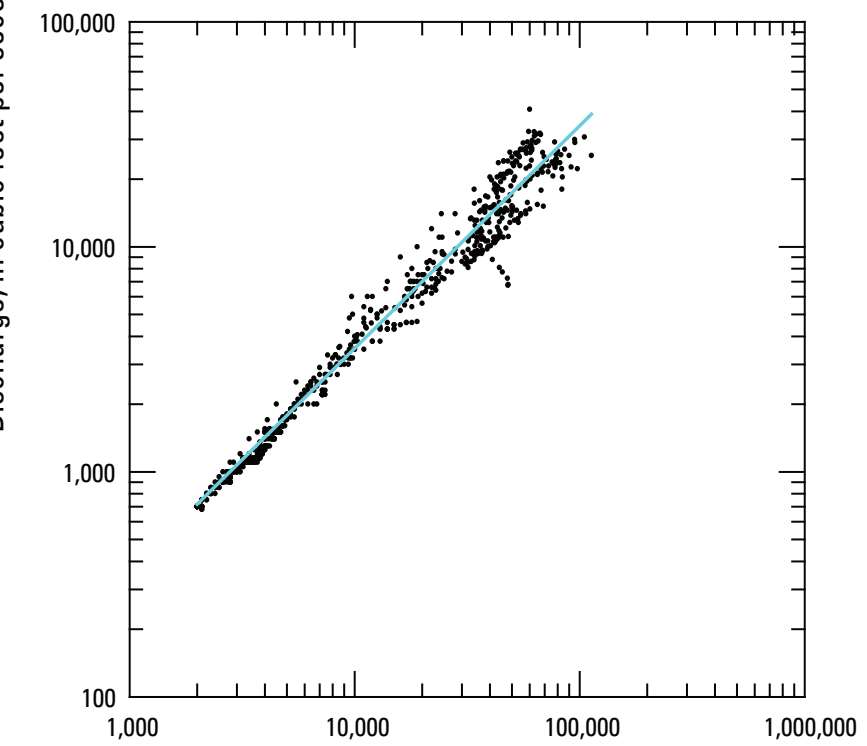

Discharge, in cubic feet per second, Yentna River near Susitna Station, Alaska

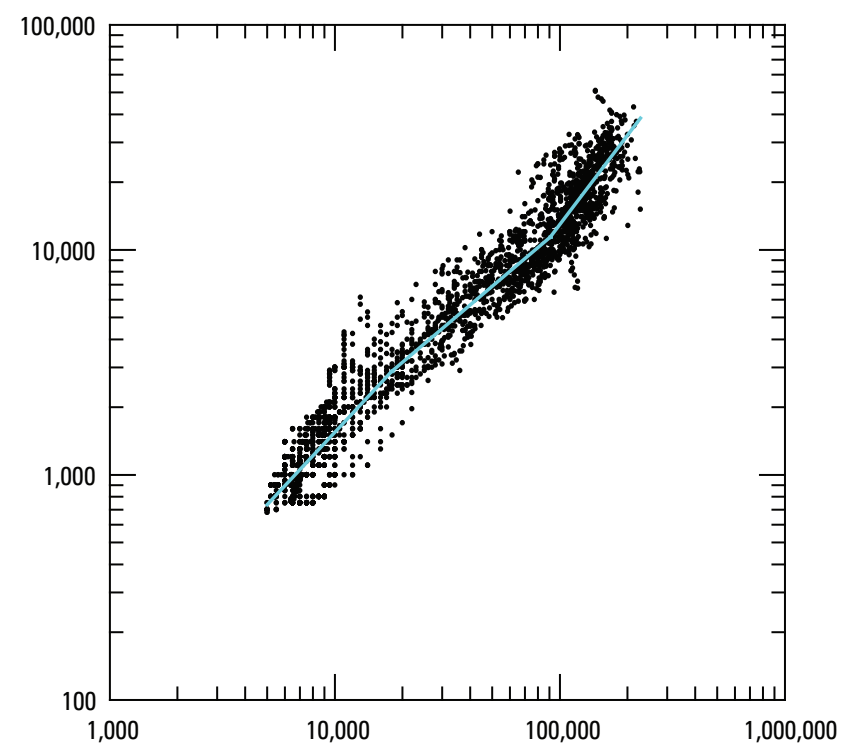

Discharge, in cubic feet per second, Susitna River at Susitna Station, Alaska

Figure A8. Correlation of concurrent daily mean discharge between Skwentna River near Skwentna and Susitna River at Gold Creek, Talkeetna River near Talkeetna, Yentna River near Susitna Station, and Susitna River at Susitna Station, Alaska, water years 1950-2010, and Kendall-Theil Robust Line regression line. 

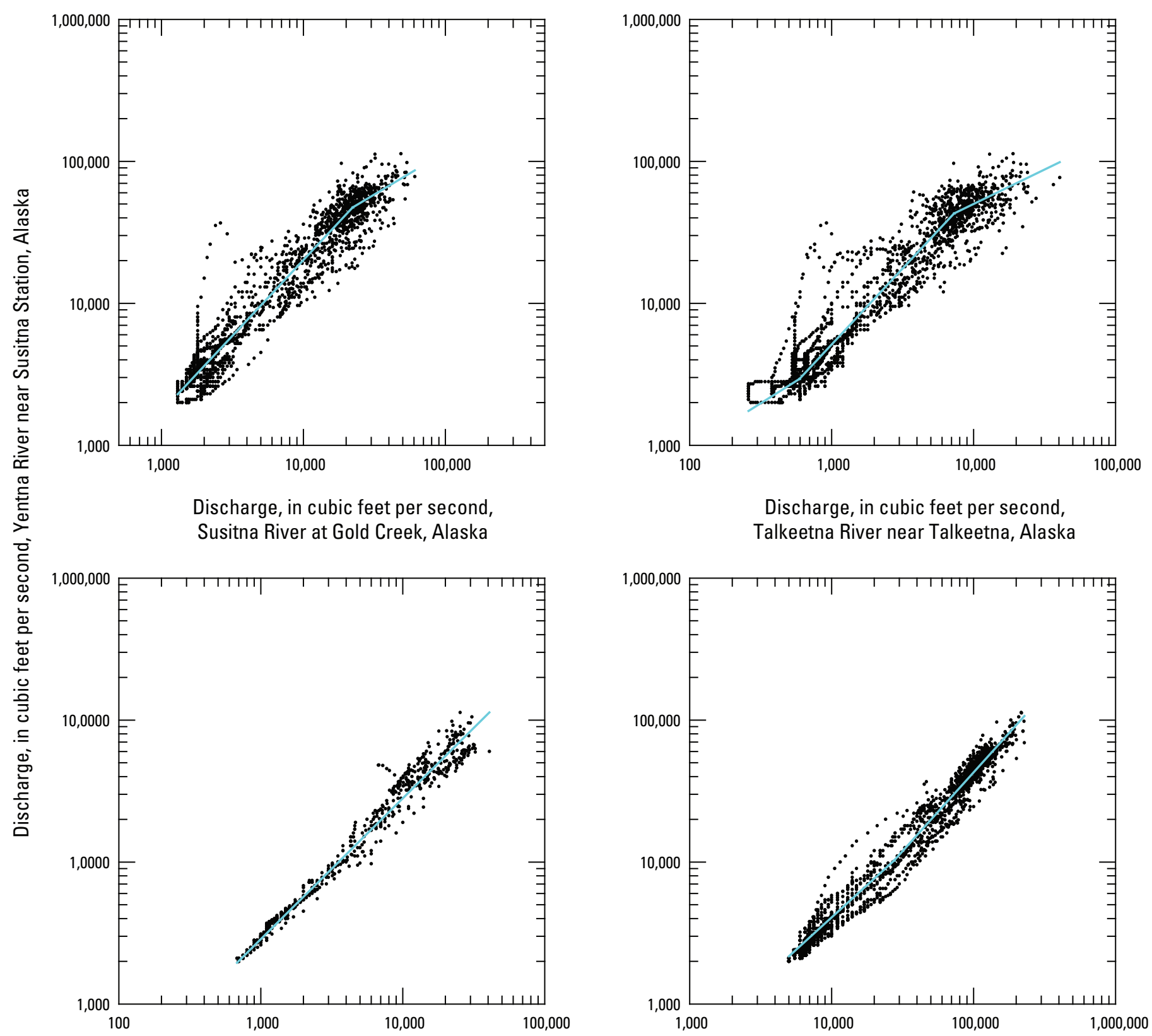

Discharge, in cubic feet per second, Skwentna River near Skwentna, Alaska

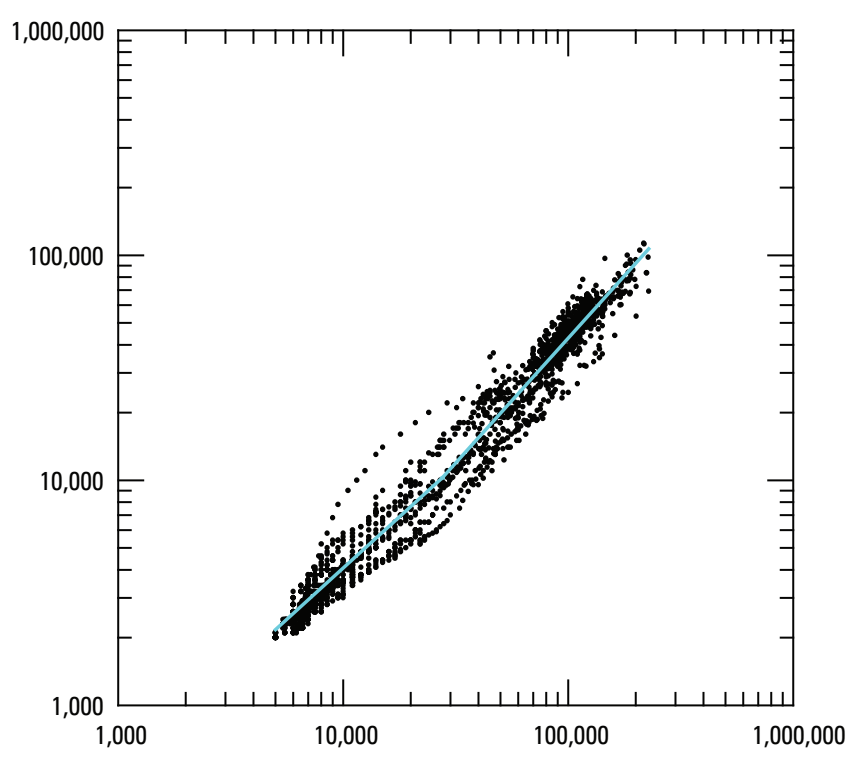

Discharge, in cubic feet per second, Susitna River at Susitna Station, Alaska

Figure A9. Correlation of concurrent daily mean discharge between Yentna River near Susitna Station and Susitna River at Gold Creek, Talkeetna River near Talkeetna, Skwentna River near Skwentna, and Susitna River at Susitna Station, Susitna River Basin, Alaska, water years 1950-2010, and Kendall-Theil Robust Line regression line. 

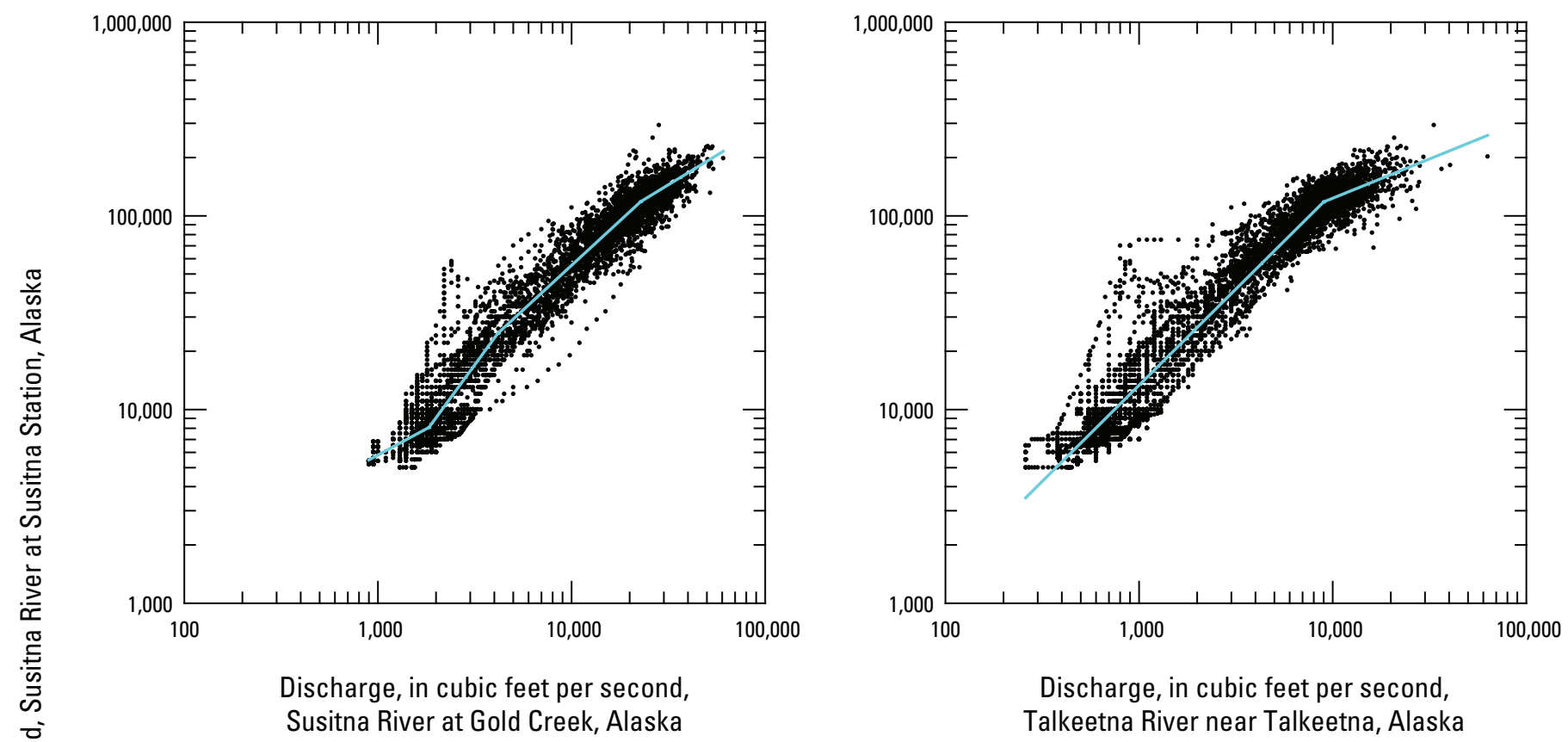

Discharge, in cubic feet per second,

Susitna River at Gold Creek, Alaska

Talkeetna River near Talkeetna, Alaska

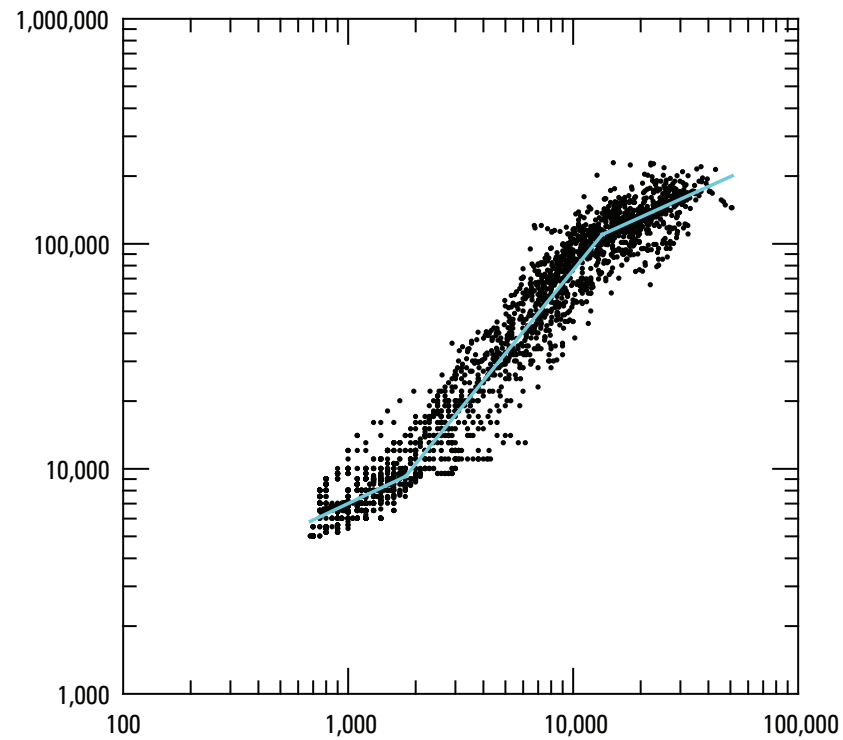

Discharge, in cubic feet per second,

Skwentna River near Skwentna, Alaska

Figure A10. Correlation of concurrent daily mean discharge between Susitna River at Susitna Station and Susitna River at Gold Creek, Talkeetna River near Talkeetna, and Skwentna River near Skwentna, Susitna River Basin, Alaska, water years 1950-2010, and Kendall-Theil Robust Line regression line. 


\section{Appendix B. Extended and Observed Streamflow Records for Water Years 1950-2010 for Selected Streamgages, Susitna River Basin, Alaska}

(M icrosoft ${ }^{\circledR}$ Excel file available for download at http://pubs.usgs.gov/sir/2012/5210) 
This page intentionally blank. 
Publishing support provided by the U.S. Geological Survey

Publishing Network, Tacoma Publishing Service Center

For more information concerning the research in this report, contact the Director, Alaska Science Center

U.S. Geological Survey

4210 University Dr.

Anchorage, Alaska 99508-4560

http://alaska.usgs.gov 


\section{खू}

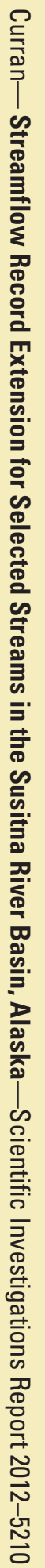

